\title{
Dihydropyridine-sensitive Calcium Current Mediates Neurotransmitter Release from Bipolar Cells of the Goldfish Retina
}

\author{
Masao Tachibana, Takashi Okada, Tomomi Arimura, Katsunori Kobayashi, and Marco Piccolino \\ Department of Psychology, Faculty of Letters, The University of Tokyo, 7-3-1 Hongo, Bunkyo-ku, Tokyo 113, Japan
}

The release of neurotransmitter is evoked by activation of the Ca current $\left(I_{\mathrm{ca}}\right)$ at presynaptic terminals. Though multiple types of $I_{\mathrm{ca}}$ have been reported in various cells, little is known about the properties of presynaptic $I_{\mathrm{Ca}}$ in the vertebrate CNS. The aim of this article is to identify the type of $I_{\mathrm{Ca}}$ involved in the release of neurotransmitter from retinal bipolar cells. Bipolar cells with a large axon terminal were isolated enzymatically from the goldfish retina, and studied by the following techniques: (1) recordings of $I_{\mathrm{Ca}}$ in the whole-cell recording configuration, (2) visualization of intracellular free $\mathrm{Ca}^{2+}$ concentration $\left(\left[\mathrm{Ca}^{2+}\right]_{i}\right)$ with the Fura-2 imaging system, and (3) real-time electrophysiological bioassay of released excitatory amino acid transmitter by a voltage-clamped horizontal cell isolated from the catfish retina. The only $I_{\mathrm{ca}}$ found in bipolar cells was the high-voltage-activated, dihydropyridine-sensitive type. This result supports the recent study by Heidelberger and Matthews (1992). When $I_{c a}$ was activated by a short depolarizing pulse, a rapid increase of $\left[\mathrm{Ca}^{2+}\right]_{i}$ was restricted to the axon terminal. A much slower and smaller increase of $\left[\mathrm{Ca}^{2+}\right]_{\text {i }}$ was sometimes observed at the cell body, probably due to the diffusion of intracellular free $\mathrm{Ca}^{2+}$ from the axon terminal. The increase of $\left[\mathrm{Ca}^{2+}\right]_{i}$ was completely suppressed by nicardipine, suggesting that $\mathrm{Ca}^{2+}$ entered through dihydropyridine-sensitive $\mathrm{Ca}$ channels located mainly at the axon terminal. Activating $I_{\mathrm{ca}}$ of the bipolar cell evoked a transmitter-induced current in the excitatory amino acid probe (i.e., the catfish horizontal cell). Both currents were suppressed concomitantly by nifedipine but not by $\omega$-conotoxin. We conclude that the activation of dihydropyridine-sensitive $I_{c a}$ causes a localized increase of $\left[\mathrm{Ca}^{2+}\right]_{i}$ at the axon terminal of bipolar cells, and results in the release of neurotransmitter.

[Key words: Ca current, glutamate, transmitter, presynaptic terminal, synapse, retinal bipolar cells, retina]

\footnotetext{
Keceived Mar. 18, 1992; revised Nov. 30, 1992; accepted Jan. 20, 1993.

We thank Dr. Bradford Powell for critical reading of the manuscript, and Haruo Odagiri and Akihiro Yamashita for technical assistance. This work was supported by the Ministry of Education, Science and Culture (Japan) Grant-in-Aid for Scientific Research 03454126,03225206 , and 03304026 to M.T.; by The Mitsubishi Foundation to M.T.; and by Human Frontier Science Program to M.P. and to M.T. M.P. was supported by Japan Society for the Promotion of Science and by the Italian National Research Council (C.N.R.).

Correspondence should be addressed to Masao Tachibana, Department of Psychology, Faculty of Letters, The University of Tokyo, 7-3-1 Hongo, Bunkyo-ku, Tokyo 113, Japan.

"Present address: Istituto di Fisiologia Generale, Universitá di Ferrara, 44100 Ferrara, Italy.
}

Copyright (c) 1993 Society for Neuroscience $0270-6474 / 93 / 132898-12 \$ 05,00 / 0$
The release of neurotransmitter is evoked by the entry of $\mathrm{Ca}^{2+}$ into presynaptic terminals via voltage-gated Ca channels (Katz and Miledi, 1969; Llinás et al., 1981; Augustine et al., 1985; reviewed in Augustine et al., 1987). Since multiple types of voltage-gated $\mathrm{Ca}$ channels have been demonstrated in various cclls (reviewed in Bean, 1989; Carbone and Swandulla, 1989) and since these channels are different in many aspects, such as their voltage dependence, single-channel conductance, activation and inactivation kinetics, and sensitivity to pharmacological compounds (Hagiwara et al., 1975; Carbone and Lux, 1984; Armstrong and Matteson, 1985; Nowycky et al., 1985; Fox et al., 1987; Kasai et al., 1987), it is important to identify the subtype of $\mathrm{Ca}$ channels located at the presynaptic terminal.

The application of electrophysiological techniques has been hindered by the extremely small size of presynaptic terminals. Thus, in most experiments, the nature of presynaptic Ca channels has been inferred from indirect evidence mainly based on pharmacological studies of the release of neurotransmitter substances in synaptosomes (Reynolds et al., 1986; Woodward and Leslie, 1986) or cultured neurons (Perney et al., 1986; Rane et al., 1987; Hirning et al., 1988; Loudes et al., 1988). It has been suggested that $\mathrm{Ca}^{\prime+}$ entry via $\omega$-conotoxin-sensitive $\mathrm{Ca}$ channels may dominate the release of small vesicles containing only classical "fast" neurotransmitters, whereas $\mathrm{Ca}^{2+}$ influx through dihydropyridine-sensitive $\mathrm{Ca}$ channels may dominate the release of large dense-core vesicles containing peptides (Miller, 1987; Hirning et al., 1988).

The above hypothesis should be examined by recording simultaneously the Ca current $\left(I_{\mathrm{Ca}}\right)$ at the presynaptic terminal under voltage clamp and the postsynaptic responses (or the release of neurotransmitter). The presynaptic $\mathrm{Ca}$ current has been recorded from a few preparations with an extraordinarily large presynaptic terminal, such as squid giant synapses (Llinás et al., 1981; Augustine et al., 1985; Smith et al., 1985; Charlton and Augustine, 1990), calyces of ciliary ganglia of chick embryo (Stanley and Atrakchi, 1990; Yawo, 1990), and rat neurohypophyses (Lemos and Nowycky, 1989; Wang et al., 1992).

Onc typc of bipolar cells (on-typc cells with mixcd rod and cone inputs) in cyprinid retinas has an extremely large axon terminal (Ishida et al., 1980; Saito and Kujiraoka, 1982). Previous experiments, using the whole-cell recording method, suggested the presence of dihydropyridine-sensitive Ca current $\left(I_{\mathrm{Ca}}\right)$ in these neurons (Kaneko et al., 1989; Tachibana and Okada, 1991). Recently, we developed a preparation useful for the study of the mechanism of neurotransmitter release (Tachibana and Okada, 1991). This preparation enabled us to monitor simultaneously both the $I_{\mathrm{Ca}}$ and the release of endogenous neurotransmitter (an excitatory amino acid, very probably glutamate) 
from a single on-type bipolar cell. The present study employed this preparation to investigate what type of presynaptic $I_{\mathrm{Ca}}$ mediates the release of excitatory amino acid transmitter from retinal bipolar cells. In addition, changes of intracellular free $\mathrm{Ca}^{2+}$ concentration $\left(\left[\mathrm{Ca}^{2+}\right]_{i}\right)$ were monitored by the Fura- $2 \mathrm{im}-$ aging system.

Part of the work has been already reported elsewhere (Tachibana et al., 1991) and was presented at the 14th International Symposium of the Taniguchi Foundation on Visual Science held November 1991. While this work was in progress, an article was published hy Heidelherger and Matthews (1992) with essentially similar results on the characterization of $I_{\mathrm{Ca}}$ by using the same type $\mathrm{if}$ bipolar cells isolated from the goldfish retina. However, concerning the changes of $\left[\mathrm{Ca}^{2+}\right]_{i}$ the interpretation of Heidelberger and Matthews is different from that of the present work.

\section{Materials and Methods}

Preparation of isolated neurons. Bipolar cells were obtained from the retina of goldfish (total body length, $15-20 \mathrm{~cm}$ ). The details of dissociation procedures have been described previously (Tachibana, 1981; Tachibana and Okada, 1991). In short, eyes were enucleated from pithed goldfish. The retinas were pretreated with a low- $\mathrm{Ca}^{2+}$ solution containing hyaluronidase $(0.1 \mathrm{mg} / \mathrm{ml}$; Sigma H-3506) and then incubated with a low- $\mathrm{Ca}^{2+}$ solution containing cysteine-activated papain $5 \mathrm{~mm}$ L-cysteine hydrochloride (Tokyo Chemical Industry Co. Ltd., Tokyo, C0517), $4 \mathrm{mg} / \mathrm{ml}$ papain (Wako Pure Chemical Industries, Ltd., Osaka, 164$00172)$ ]. The composition of the low-Ca ${ }^{2+}$ solution was (in $\mathrm{mm}$ ) $\mathrm{NaCl}$, 120; KCl, 2.6; $\mathrm{NaHCO}_{3}, 1 ; \mathrm{NaH}_{2} \mathrm{PO}_{4}, 0.5 ; \mathrm{Na}$-pyruvate, 1; glucose, 16; HEPES, 4 (pH adjusted to 7.2 with $\mathrm{NaOH}$ ). After the retinas were rinsed with a standard solution, they were mechanically triturated using a largetip pipette $(\sim 1.5 \mathrm{~mm}$ internal diameter). The standard solution contained (in mM) $\mathrm{NaCl}, 120 ; \mathrm{KCl}, 2.6 ; \mathrm{CaCl}_{2}, 2.5 ; \mathrm{MgCl}_{2}, 1$; glucose, 10; and HEPES, 10 ; with $0.1 \mathrm{mg} / \mathrm{ml} \mathrm{BSA} \mathrm{(pH}$ adjusted to 7.4 with $\mathrm{NaOH}$ ). A few drops of cell suspension were placed in a culture dish (Falcon 3001).

Recordings were made from bipolar cells with a large bulb-like axon terminal. In the intact retina these cells receive inputs from both rods and cones, and respond with membrane depolarization to the illumination of their receptive field center (on-type cells; Saito and Kujiraoka, 1982). The isolated on-type bipolar cells were used for experiments within a few hours after dissociation.

In experiments aimed to study the neurotransmitter release (release experiments), cone horizontal cells dissociated from the retina of catfish (total body length, 12-17 cm) were used as a probe of excitatory amino acids (Tachibana and Okada, 1991). These cells contain both $N$-methylD-aspartic-acid (NMDA) receptors and non-NMDA receptors, and are able to detect submicromolar concentrations of L-glutamate when the NMDA receptors are potentiated by $10 \mu \mathrm{M}$ glycine. Although catfish horizontal cells contain also $\mathrm{GABA}_{\mathrm{A}}$ receptors, the response evoked by a saturating dose $(100 \mu \mathrm{M})$ of GABA is very small (Tachibana and Okada, 1991). The dissociation procedure was the same as mentioned above, except that the catfish retina was not pretreated with hyaluronidase. A few drops of cell suspension were placed in culture dishes (Falcon 3001) that contained $2 \mathrm{ml}$ of Ames' solution (Sigma A-1420; $\mathrm{pH}$ adjusted to 7.4 with HEPES buffer); cultures were maintained at $15^{\circ} \mathrm{C}$ in a low-temperature incubator for $1-6 \mathrm{~d}$ prior to being used for release experiments.

Recordings of the Ca current from goldfish bipolar cells. A culture dish was inserted into a temperature-controlled water jacket mounted on the stage of an inverted microscope equipped with phase-contrast optics (Olympus IMT-2 or Nikon TMD). A stainless steel ring was put into the dish to reduce the volume of superfusate and to facilitate heat exchange. Cells isolated from the goldfish retina were continuously superfused with the standard solution pumped at the rate of $0.24-0.60$ $\mathrm{ml} / \mathrm{min}$. Experiments were carried out between $15^{\circ} \mathrm{C}$ and $16^{\circ} \mathrm{C}$.

Bipolar cells with a huge axon terminal were voltage clamped by a patch pipette (resistance measured in the bath solution, $\sim 10 \mathrm{M} \Omega$ ) in the whole-cell recording configuration (Hamill et al., 1981). The series resistance $\left(R_{s}\right)$, estimated with the $R_{s}$ compensation circuitry of the List EPC-7 patch-clamp amplifier, ranged typically from 20 to $30 \mathrm{M} \Omega$. When the membrane current was less than $200 \mathrm{pA}$ in amplitude, the compensation of $R_{\mathrm{r}}$ (approximately $50 \%$ compensation by the electrical circuit of EPC-7) did not cause appreciable changes in the amplitude and waveform of the current. However, an escape from clamp was observed when the current amplitude was much larger than $200 \mathrm{pA}$. Since the $R_{s}$ compensation was not routinely used in the present study, the results are described rather qualitatively when the amplitude of the current was much larger than $200 \mathrm{pA}$.

The patch pipette contained (in $\mathrm{mM}$ ) $\mathrm{CsCl}, 120 ; \mathrm{CaCl}_{2}, 0.5$; EGTA. $5 ; \mathrm{MgCl}_{2}, 2 ; \mathrm{Na}_{2} \mathrm{ATP}, 5 ; \mathrm{HEPES}, 10$ (pH adjusted to 7.2 with $\mathrm{CsOH}$ ). In some cases, EGTA ( $5 \mathrm{~mm}$ ) was replaced with BAPTA (1 mM) and the osmolarity was adjusted by adding $\mathrm{CsCl}$. Voltage-activated and $\mathrm{Ca}$ mediated K currents (Kaneko and Tachibana, 1985) were almost completely suppressed by the $\mathrm{Cs}^{+}$pipette solution containing 5 mM EGTA. In some experiments, the superfusate was changed from the standard solution to a tetraethylammonium (TEA) solution, in which $\mathrm{Na}^{+}$and $\mathrm{K}^{+}$were totally replaced with TEA, but the amplitude and time course of membrane currents showed no significant change.

The recording pipette was positioned either at the cell body or at the axon terminal. The normalized $I_{C}$-membrane potential curve obtained at the axon terminal was almost identical to that at the cell body, suggesting that the space-clamp condition of bipolar cells was satisfied.

Pharmacological agents, such as Bay K 8644 (Calbiochem 196878), nicardipine (Sigma N-7510), nifedipine (Sigma N-7634), and $\omega$-conotoxin GVIA (Peptide Institute, Inc., Osaka, Japan, 4161), were dissolved in the same solution as the superfusate, and applied through a "Y"tube microflow system (Suzuki et al., 1990). Its outlet was positioned at a close distance $(<500 \mu \mathrm{m})$ from the cell under investigation.

Measurement of intracellular Ca ion concentration. Intracellular concentration of free $\mathrm{Ca}^{2+}\left(\left[\mathrm{Ca}^{2+}\right]_{i}\right)$ in isolated bipolar cells was measured by using Fura-2, a fluorescent $\mathrm{Ca}^{2+}$ indicator (Grynkiewicz et al., 1985). When $I_{\mathrm{Ca}}$ was not recorded, bipolar cells were loaded with a membranepermeable acetoxymethyl ester form of Fura-2 (Fura-2/AM; Dojindo Lab., Kumamoto, Japan, 348-05831). Fura-2/AM dissolved in dimethyl sulfoxide (DMSO; $1 \mathrm{~mm}$ stock solution) was added to the standard solution at the final concentration of 1-5 $\mu \mathrm{M}$. To improve the solubilization of Fura-2/AM, pluronic F-127 (25\% w/w in DMSO) was added to the Fura-2/AM solution $(2.5 \mu \mathrm{l} / \mathrm{ml})$. Bipolar cells were incubated with this Fura-2/AM solution for $20-30 \mathrm{~min}$ at $15-20^{\circ} \mathrm{C}$, and then rinsed with the standard solution for more than $20 \mathrm{~min}$. To estimate the percentage of the Fura-2/AM that had been converted to the $\mathrm{Ca}^{2+}$ sensitive form, bipolar cells loaded with Fura-2/AM $(5 \mu \mathrm{M})$ were exposed to the external solution containing 2-5 $\mu \mathrm{M} \mathrm{Ca}^{2+}$ ionophore [4-Br-calcium ionophore A23187 (Sigma B-7272) or ionomycin (Sigma I-0634)] and $3.5 \mathrm{mM} \mathrm{Mn}^{2+}$ to quench the fluorescence of deesterified Fura-2. It was found that $96 \pm 1 \%$ (mean $\pm \mathrm{SD} ; n=8$ cells examined) of cellular fluorescence was quenched by this procedure, indicating that most of the intracellularly accumulated Fura-2/AM was effectively converted to Fura-2 and that the $\mathrm{Ca}^{2+}$ indicator was mostly accessible to ionophoremediated divalent cation influx. $I_{\mathrm{Ca}}$ of a Fura-2-loaded bipolar cell was activated by the application of a high- $\mathrm{K}^{+}(130 \mathrm{~mm})$ solution ejected from a large-tip (2-5 $\mu \mathrm{m}$ in diameter) pipette by pressure (Tachibana, 1985).

In experiments, where $\left[\mathrm{Ca}^{2+}\right]_{i}$ and $I_{\mathrm{Ca}}$ were simultaneously monitored, Fura-2 (pentapotassium salt; Dojindo Lab., Kumamoto, Japan, 34705421 ) was introduced into a bipolar cell via a recording pipette. Fura-2 $(100 \mu \mathrm{M})$ was dissolved in the $\mathrm{Cs}^{+}$pipette solution, which contained no EGTA to minimize effects of exogenous $\mathrm{Ca}^{2+}$ buffers on changes of $\left[\mathrm{Ca}^{2+}\right]_{i}$ (osmolarity adjusted with $\left.\mathrm{CsCl}\right)$. In some experiments EGTA (1 or $5 \mathrm{~mm}$ ) was included in the pipette solution. The patch pipette was positioned either at the axon terminal or at the cell body, but neither $I_{C_{\mathrm{a}}}$ nor $\left[\mathrm{Ca}^{2+}\right]_{i}$ was affected by the position of the recording pipette. The measurement of $\left[\mathrm{Ca}^{2+}\right]_{i}$ was started approximately $5 \mathrm{~min}$ after the rupture of the patch membrane, when the intensity of Fura-2 fluorescence became strong enough to be detected by a silicon-intensified target (SIT) camera (C2400-08, Hamamatsu Photonics, Hamamatsu, Japan). Fluorescence of Fura-2-loaded single bipolar cell was imaged using a $100 \times$ oil immersion objective (Nikon NCF Fluor; NA $=1.30$ ) and an inverted microscope equipped for epifluorescence (Nikon TMD with a $100 \mathrm{~W}$ Xe lamp). Video images were obtained using the SIT camera, and its output was fed into the image processor (ARGUS-100/CA system, Hamamatsu Photonics). The images were digitized to a spatial resolution of $256 \times 241$ pixels with an 8-bit intensity resolution. To correct for the spatial variations in dark current of the camera, an averaged image, obtained without UV-light illumination of the preparation, was sub- 


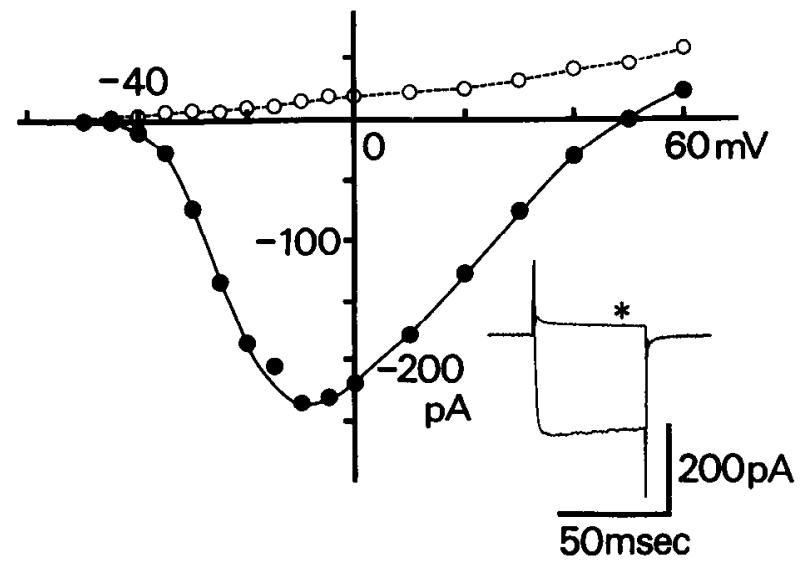

Figure 1. Voltage dependence of the Ca current. Inset, Sampled current recordings from a bipolar cell under whole-cell voltage clamp. The cell was depolarized for $50 \mathrm{msec}$ from the holding potential of $-70 \mathrm{mV}$ to $-10 \mathrm{mV}$ in the absence and presence $\left(^{*}\right)$ of $\mathrm{Co}^{2+}(3.5 \mathrm{~mm})$. Patch pipette was filled with the $\mathrm{Cs}^{+}$solution containing EGTA (5 mM). Currents were low-pass filtered at $2.5 \mathrm{kHz}$. Current-voltage relationship, Peak amplitude of the current was plotted against the membrane potential. Solid circles indicate the values in the standard solution, and open circles, the values in the presence of $\mathrm{Co}^{2+}$. The Ca current $\left(I_{\mathrm{Ca}}\right)$ could be obtained by subtracting the values indicated by open circles from that displayed by solid circles at corresponding potentials.

tracted from each fluorescence image on a pixel-by-pixel basis. An image of Fura-2 fluorescence at $510 \mathrm{~nm}$ emission was taken with $360 \mathrm{~nm}$ excitation wavelength. Then, a series of $510 \mathrm{~nm}$ fluorescence images were obtained at the rate of $10-15$ frames/sec with $340 \mathrm{~nm}$ excitation wavelength. Finally, a fluorescence image was taken again with $360 \mathrm{~nm}$ excitation wavelength. The excitation intensities were adjusted to minimize the photoblcaching and the generation of fluorescent photoproducts by inserting quartz neutral density filters to the light paths; the fluorescence intensity of the last $360 \mathrm{~nm}$ image decreased to approximately $90 \%$ of that of the first $360 \mathrm{~nm}$ image after $5 \mathrm{sec}$ exposure of $340 \mathrm{~nm}$ light. After smoothing each image by a $3 \times 3$ matrix averager, the ratio image was achieved from the division of the $340 \mathrm{~nm}$ image by the corresponding $360 \mathrm{~nm}$ image that was interpolated linearly using the first and the last $360 \mathrm{~nm}$ images. A fluorescence intensity threshold was set before the division in order to exclude noncellular regions from the determination of the ratio image. In some experiments, where a long-term change of $\left[\mathrm{Ca}^{2+}\right]_{i}$ was monitored, the preparation was illuminated by alternating $340 \mathrm{~nm}$ and $380 \mathrm{~nm}$ lights every $1 \mathrm{sec}$, and the ratio images were calculated by the division of $340 \mathrm{~nm}$ image by the corresponding $380 \mathrm{~nm}$ image.

The relationship between the Fura-2 fluorescence and the free $\mathrm{Ca}^{2+}$ concentration was calibrated in vitro. Fura-2 $(20 \mu \mathrm{M})$ was added to 200 $\mu$ l of $\mathrm{Ca}^{2+}$ buffer solutions (EGTA, $10 \mathrm{~mm}$; $\mathrm{CsCl}, 110 \mathrm{~mm}$; HEPES, 10 $\mathrm{mm} ; \mathrm{KOH}, 50 \mathrm{~mm} ; \mathrm{CaCl}_{2}, 0-10 \mathrm{~mm}$; $\mathrm{pH} 7.20$ adjusted by $\mathrm{HCl}$ ), and the intensity ratio of fluorescence was measured for each buffer solution as described above. This in vitro calibration provided us only with a rough estimation of $\left[\mathrm{Ca}^{2+}\right]$, because it has been reported that the Fura-2 fluorescence is affected by various intracellular factors (Williams and Fay, 1990; Uto et al., 1991). In this article, therefore, we focused our analysis on the spatial and temporal changes of $\left[\mathrm{Ca}^{2+}\right]_{i}$ and not on the absolute level of $\left[\mathrm{Ca}^{2+}\right]_{i}$.

Recording procedures for release experiments. A culture dish, in which catfish horizontal cells had been maintained, was mounted on the stage of an inverted microscope, and a freshly prepared goldfish retinal cell suspension was dropped into the dish. A patch pipette filled with the $\mathrm{Cs}^{+}$pipette solution was positioned at the axon terminal of a goldfish bipolar cell, and then the cell was voltage clamped at $-70 \mathrm{mV}$ in the whole-cell recording configuration. A catfish horizontal cell was voltage clamped at +30 or $+40 \mathrm{mV}$ by another patch pipette filled with the $\mathrm{Cs}^{+}$pipette solution supplemented with $0.5 \mathrm{~mm}$ cAMP. Finally, the bipolar cell was transported onto the horizontal cell by manipulating the recording pipette, and then the axon terminal of the bipolar cell was gently pushed against the horizontal cell (Tachibana and Okada, 1991). To potentiate the NMDA receptors of catfish horizontal cells, the bi- polar-horizontal cell pair was superfused with the solution containing $10 \mu \mathrm{M}$ glycine, which was ejected from the Y-tube microflow system. Pharmacological compounds were dissolved in the glycine-containing solution and were applied from the same $\mathrm{Y}$-tube microflow system.

Current and voltage signals from two patch-clamp amplifiers (Nihon Kohden CEZ-2200 and List EPC-7) were monitored on an oscilloscope and a pen recorder, and stored by a PCM recorder (Sony PC-108M, DC to $10 \mathrm{kHz}$ ). At the same time, data were passed through a low-pass filter (NF Electronic Instruments, Yokohama, SR-4FL) to eliminate aliasing, sampled and digitized by an A/D converter (Canopus, ADX$98 \mathrm{H}$; sampling speed, $0.1-1 \mathrm{kHz}$ ) connected to a computer (NEC, PC9801-RX), and stored on a hard disk for later analysis.

Each result reported in this article was based on the observations obtained from at least three bipolar cells or three pairs of bipolar and horizontal cells, if not otherwise specified.

\section{Results}

\section{Ideritification of subtype of Ca current}

We investigated the properties of the Ca current $\left(I_{\mathrm{Ca}}\right)$ of on-type bipolar cells with a huge bulb-like axon terminal to identify the subtype of Ca channels. The voltage-activated and $\mathrm{Ca}$-mediated K currents (Kaneko and Tachibana, 1985) were almost completely eliminated by $\mathrm{Cs}^{+}$and EGTA introduced via patch pipette. When the membrane potential was changed from the holding potential of $-70 \mathrm{mV}$ to potentials more positive than approximately $-45 \mathrm{mV}$, an inward current with a slow decay was evoked (Fig. 1, inset, current trace without asterisk). The amplitude of the inward current increased as the membrane potential was shifted up to $-10 \mathrm{mV}$, and decreased with much larger depolarization (Fig. 1, solid circles).

The inward current was almost completely suppressed when the extracellular $\mathrm{Ca}^{2+}$ was replaced with $\mathrm{Co}^{2+}$, a $\mathrm{Ca}$ channel blocker (Fig. 1, inset, current trace with asterisk). There was no apparent voltage and time dependence in the remaining current. The current-voltage relationship in the presence of $\mathrm{Co}^{2+}$ was nearly linear and the membrane resistance was very high $(\sim 2$ G $\Omega$ ) (Fig. 1, open circles). Therefore, the current in the presence of $\mathrm{Co}^{2+}$ consisted mostly of a leakage current. The effect of $\mathrm{Co}^{2+}$ was reversible upon washout. Divalent cations such as $\mathrm{Cd}^{2+}$ and $\mathrm{Ni}^{2+}$ also suppressed the inward current strongly (not illustrated; but see Tachibana and Okada, 1991, their Figs. 8, 9). The order of potency in blocking, estimated by the concentration that caused half-inhibition, was $\mathrm{Cd}^{2+}(23 \mu \mathrm{M})>\mathrm{Ni}^{2+}(50 \mu \mathrm{M})>\mathrm{Co}^{2+}(120$ $\mu \mathrm{M})>\mathrm{Mn}^{2+}(420 \mu \mathrm{M})>\mathrm{Mg}^{2+}(5.3 \mathrm{mM})$.

When $\mathrm{Ca}^{2+}$ in the superfusate was increased from 2.5 to 10 $\mathrm{mM}$, the amplitude of the inward current also increased (not illustrated). The current increased further after the replacement of $10 \mathrm{mM} \mathrm{Ca}^{2+}$ with equimolar $\mathrm{Ba}^{2+}$ or $\mathrm{Sr}^{2+}$. The order and relative value of current amplitude were $\mathrm{Ba}^{2+}(1.9)>\mathrm{Sr}^{2+}$ (1.4) $>\mathrm{Ca}^{2+}(1.0)$. These observations demonstrated that the inward current after leakage subtraction was carried mainly by $\mathrm{Ca}^{2+}$ through $\mathrm{Ca}$ channels.

$I_{\mathrm{Ca}}$ was activated at potentials more positive than $-45 \mathrm{mV}$, and the maximal current $\left(I_{\max }: 291 \pm 51 \mathrm{pA}, n=6\right)$ was evoked at approximately $-10 \mathrm{mV}$ (Fig. 1). The current with $5 \%$ of $I_{\max }$ was induced at $-42 \pm 1 \mathrm{mV}(n=6)$. Depolarization to potentials more positive than $-10 \mathrm{mV}$ reduced the amplitude of $I_{\mathrm{Ca}}$, mainly due to the decrease of driving force for $\mathrm{Ca}^{2+}$.

No inward current was evoked at potentials more negrtive than $-50 \mathrm{mV}$ even when the holding potential was set tc -90 $\mathrm{mV}$ or $-100 \mathrm{mV}$ (not illustrated). Furthermore, even at the holding potential of $-50 \mathrm{mV}$, where the low-voltage-activated $I_{\mathrm{Ca}}$ is known to be almost completely inactivated, depolarizing pulses evoked $I_{\mathrm{Ca}}$ comparable to that induced from more negative 


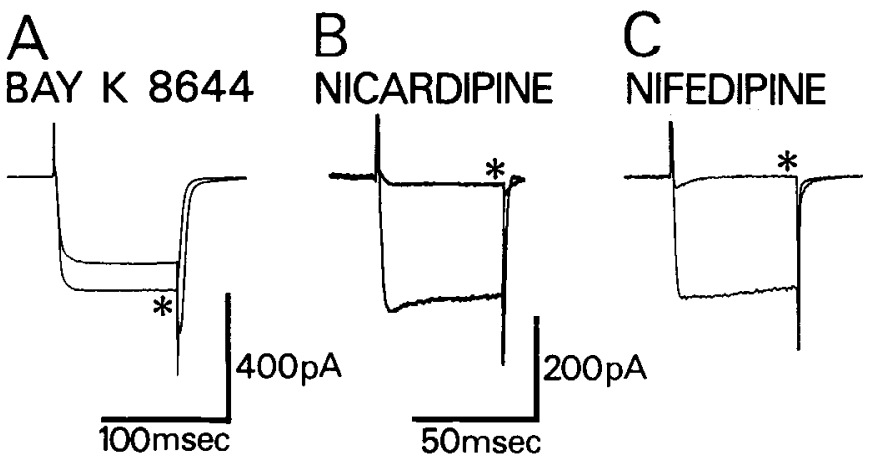

holding potentials. Thus, we concluded that on-type bipolar cells of the goldfish retina were equipped with the high-voltage-activated $I_{\mathrm{Ca}}$. The low-voltage-activated $I_{\mathrm{Ca}}$ was not detected in this preparation.

Under the experimental condition, in which 5 mM EGTA was included in the pipette solution, $I_{\mathrm{Ca}}$ showed very slow decay and could be maintained during depolarizing pulses ( $>500 \mathrm{msec}$ in duration) (not illustrated; see also Tachibana and Okada, 1991), indicating that $I_{\mathrm{Ca}}$ was of the sustained type.

High-voltage-activated $I_{\mathrm{Ca}}$ is classified into two pharmacologically distinct types: the dihydropyridine-sensitive type and the $\omega$-conotoxin-sensitive type (Aosaki and Kasai, 1989). To ascertain the nature of the $I_{\mathrm{Ca}}$ of goldfish on-type bipolar cells, we tested the effect of these pharmacological agents.

Dihydropyridine compounds were powerful in modifying $I_{\mathrm{Ca}}$, as reported previously by Kaneko et al. (1989) in the same preparation. $I_{\mathrm{Ca}}$ was potentiated greatly by Bay K $8644(0.3 \mu \mathrm{M})$ (Fig. $2 A$ ). On the other hand, nicardipine blocked $I_{\mathrm{Ca}}$ strongly (Fig. $2 B$ ). As reported for other dihydropyridine blockers (Bean, 1984; Sanguinetti and Kass, 1984), the blocking effect of nicardipine was affected seriously by the holding potential. The concentrations that caused half-inhibition of $I_{\mathrm{Ca}}$ were $0.2 \mu \mathrm{M}, 0.7$ $\mu \mathrm{M}$, and $1.2 \mu \mathrm{M}$ at the holding potentials of $-50 \mathrm{mV},-70 \mathrm{mV}$, and $-90 \mathrm{mV}$, respectively (not illustrated). Partial recovery was observed upon prolonged washout. Nifedipine also suppressed $I_{\mathrm{Ca}}$ (Fig. $2 C$ ), but it was less effective than nicardipine, and higher concentrations were required for current blockade. Nifedipine at $3 \mu \mathrm{M}$ reduced the amplitude of $I_{\mathrm{Ca}}$ to half at the holding potential of $-60 \mathrm{mV}$. Nifedipine showed a better recovery upon washout than nicardipine.

$\omega$-Conotoxin did not block $I_{\mathrm{Ca}}$ even at the concentration of $1-5 \mu \mathbf{M}(n=12)$ (Fig. $2 D)$. This concentration has been reported to suppress very strongly the $\omega$-conotoxin-sensitive $I_{\mathrm{Ca}}$ of other preparations (Kerr and Yoshikami, 1984; Fox et al., 1987; Kasai et al., 1987; Aosaki and Kasai, 1989). On four occasions we were able to test the effect of both drugs on the same bipolar cell: in all cells $\omega$-conotoxin was ineffective whereas nifedipine had a strong inhibitory action (Fig. $2 C, D$ ).

This series of experiments demonstrated that the $I_{\mathrm{Ca}}$ of goldfish bipolar cells with a large axon terminal was of the highvoltage-activated, dihydropyridine-sensitive type, and that neither the low-voltage-activated type nor the $\omega$-conotoxin-sensitive type was detected in these cells. These results confirm the recent report of Heidelberger and Matthews (1992) on the iden-

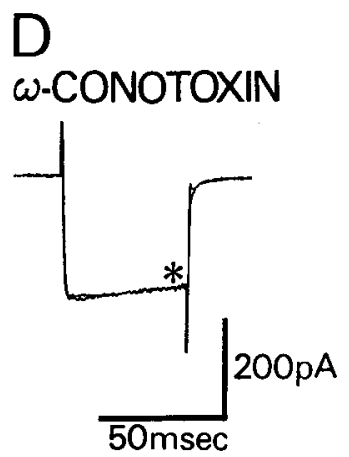

Figure 2. Effects of dihydropyridines and $\omega$-conotoxin on the $\mathrm{Ca}$ current. Superimposed current traces were recorded in the presence $(*)$ and absence of pharmacological agent. Cells were depolarized from the holding potential of $-70 \mathrm{mV}$ to $-20 \mathrm{mV}$ for $100 \mathrm{msec}(A)$ or $50 \mathrm{msec}(B-D) . A$, Potentiation of $I_{\mathrm{Ca}}$ and the tail current by Bay K $8644(0.3$ $\mu \mathrm{M}) . B$, Blockade by nicardipine $(10 \mu \mathrm{M})$. $C$, Blockade by nifedipine $(100 \mu \mathrm{M}) . D$, No blockade by $\omega$-conotoxin $(5 \mu \mathrm{M})$ Current recordings shown in $C$ and $D$ were obtained from the same bipolar cell. Same calibration applies to $C$ and $D$. Recording pipette was filled with the $\mathrm{Cs}^{+}$pipette solution containing EGTA ( 5 mM). Currents were low-pass filtered at $1 \mathrm{kHz}(A)$ or at $2.5 \mathrm{kHz}(B-D)$.

tification of $I_{\mathrm{Ca}}$ recorded from the same type of bipolar cells isolated from the goldfish retina.

Changes of intracellular free $\mathrm{Ca}^{2+}$ concentration in response to the activation of the Ca current

To gain insight into the physiological function of $I_{\mathrm{Ca}}$ of bipolar cells, we measured the magnitude and spatiotemporal changes of intracellular free $\mathrm{Ca}^{2+}$ concentration $\left(\left[\mathrm{Ca}^{2+}\right]_{i}\right)$ induced by the activation of $I_{\mathrm{Ca}}$ using Fura-2-loaded single bipolar cells.

First we examined changes of $\left[\mathrm{Ca}^{2+}\right]_{i}$ elicited by the application of a high- $\mathrm{K}^{+}$solution in bipolar cells, which were previously incubated with Fura-2/AM, a membrane-permeable derivative of Fura-2. Since whole-cell recordings were not carried out in these cells, their intracellular environment was not perturbed by the diffusion of pipette solution but $I_{\mathrm{Ca}}$ could not be monitored.

At the resting state the spatial distribution of intracellular free $\mathrm{Ca}^{2+}$ was sometimes heterogeneous (Fig. $3 \mathrm{~A}$; see also below). However, there was no consistent tendency for the resting free $\mathrm{Ca}^{2+}$ level to be higher at a special part of the axon terminal (49 cells examined).

To activate $I_{\mathrm{Ca}}$, a high-K $\mathrm{K}^{+}$solution $\left(130 \mathrm{~mm} \mathrm{~K} \mathrm{~K}^{+}\right)$was cjccted toward the Fura-2-loaded bipolar cell from a puff pipette for 3 sec. At the axon terminal the free $\mathrm{Ca}^{2+}$ level increased rapidly and almost reached a steady level less than $1 \mathrm{sec}$ after the onset of high-K $\mathrm{K}^{+}$application (Figs. $3 B-E ; 4$, trace 1 ). At each moment when fluorescence image was acquired (15 frames per $\mathrm{sec}$ ), the spatial distribution of free $\mathrm{Ca}^{2+}$ was heterogeneous at the axon terminal but " $\mathrm{Ca}^{2}$ wave" was not clearly observed.

Increased intracellular free $\mathrm{Ca}^{2+}$ appeared to spread from the axon terminal toward the cell body with time (Fig. $3 B-E$ ). As illustrated in Figure 4 , the increase in $\left[\mathrm{Ca}^{2+}\right]_{i}$ started with a longer delay at the axon fiber (trace 2) than at the axon terminal (trace 1). Furthermore, the rate of rise was slower and the amount of change was smaller at the axon fiber (trace 2) than at the axon terminal (trace 1). As the distance from the axon terminal became longer (the cell body, trace 3; the principal dendrite, trace $4),\left[\mathrm{Ca}^{2+}\right]_{i}$ increased much more slowly. In a total of 49 cells examined, similar results were obtained from 45 cells. In the remaining four cells, the increase of $\left[\mathrm{Ca}^{2+}\right]_{i}$ was restricted only to the axon terminal. The spatiotemporal difference between the axon terminal and the cell body was not related to the loading condition of Fura-2/AM (the concentration of Fura-2/AM, the incubation time, or the incubation temperature). Since bipolar 


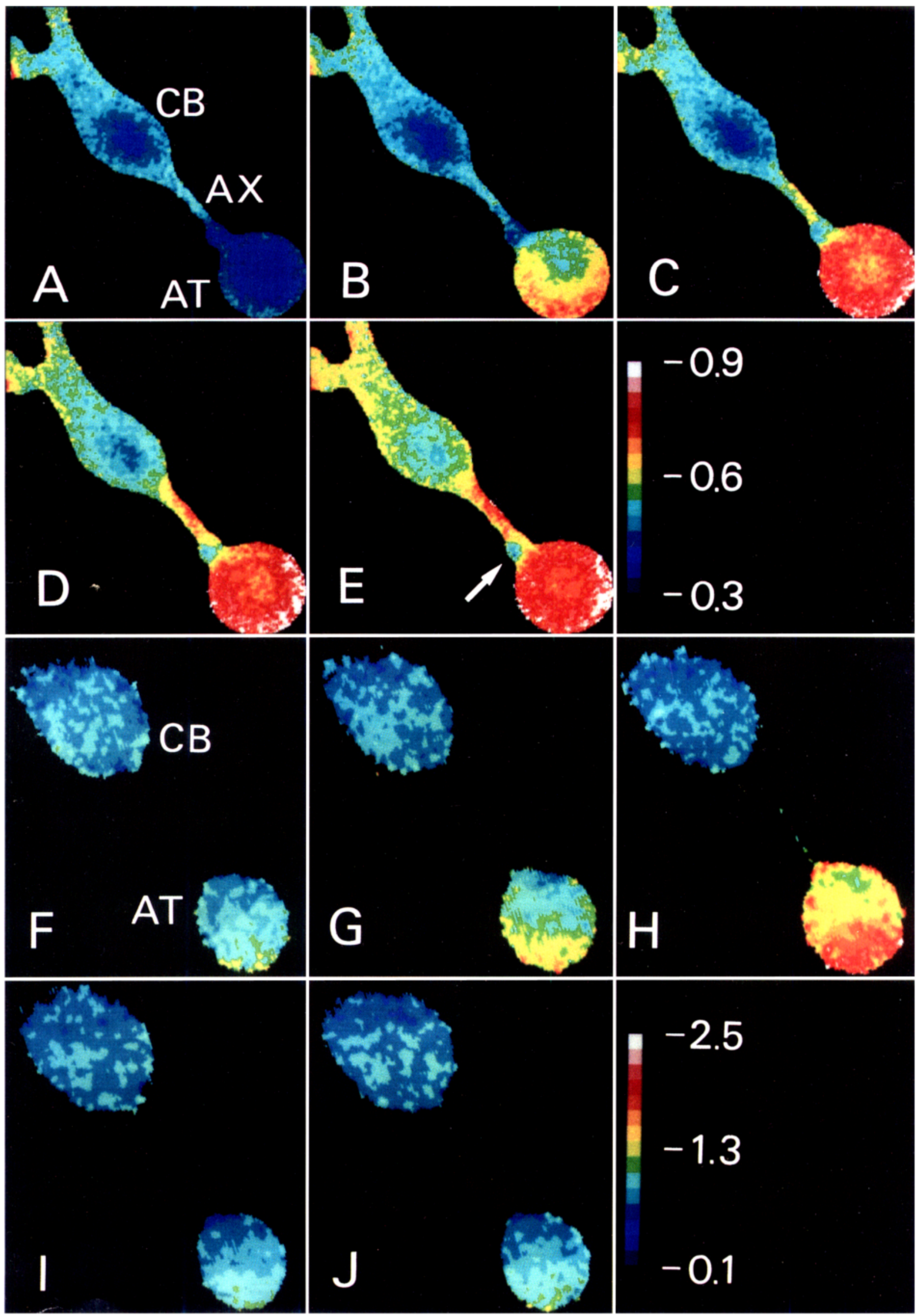




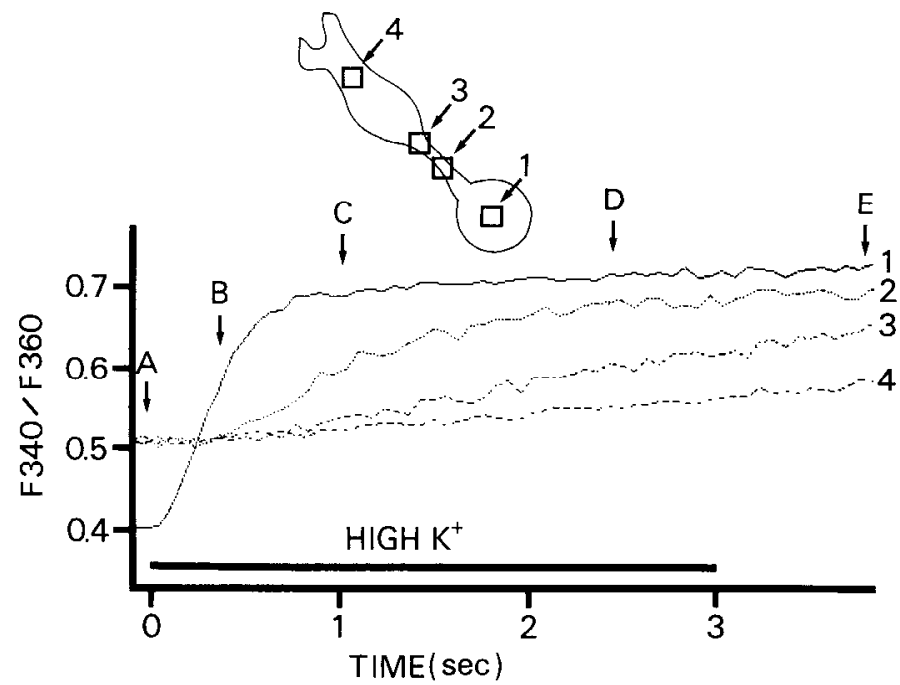

Figure 4. Temporal changes of $\left[\mathrm{Ca}^{2+}\right]_{i}$ induced by the application of the high-K+ $\mathrm{K}^{+}(130 \mathrm{~mm})$ solution. Data were obtained from the same bipolar cell illustrated in Figure $3 A-E$. The high-K $\mathrm{K}^{+}$solution was applied by pressure during the period indicated with the solid bar. Ordinate, Intensity ratio of fluorescence $\left(F_{340} / F_{360}\right)$. Image acquisition rate, 15 frames/sec. Each trace $(1-4)$ indicates the averaged fluorescence ratio in the small square region shown in the inset. $A-E$ show the time when the corresponding images of Figure 3 were sampled.

cells seemed to be equipotential (see Materials and Methods; see also Heidelberger and Matthews, 1992), such spatiotemporal pattern could not be ascribed to the heterogeneous distribution of membrane potential. These results suggest that $\left[\mathrm{Ca}^{2+}\right]_{i}$ increased rapidly at the axon terminal upon depolarization and then the increased free $\mathrm{Ca}^{2+}$ moved toward the cell body through the axon fiber by diffusion.

Soon after the offset of a puff of the high-K+ solution, the free $\mathrm{Ca}^{2}+$ level at the axon terminal started declining whereas that at the cell body continued increasing for a while (Fig. 5). This observation is also consistent with the hypothesis that the wave of free $\mathrm{Ca}^{2+}$ travels from the axon terminal to the cell body.

The magnitude of changes in $\left[\mathrm{Ca}^{2+}\right]_{i}$ induced by the high-K $\mathrm{K}^{+}$ application differed clearly between the axon terminal and the cell body (Figs. 4, 5). However, when a Ca ionophore (ionomycin or Br-A23187) was applied to Fura-2-loaded bipolar cells, the rate of rise and the final value of $\left[\mathrm{Ca}^{2+}\right]_{i}$ were very similar at both regions ( $n=12$; not illustrated). Furthermore, the regional heterogeneity of resting $\left[\mathrm{Ca}^{2+}\right]_{i}$, which was sometimes observed when the cell was loaded with a high concentration of Fura-2/ AM (see Fig. 3A), also disappeared. This observation suggests that Fura- 2 in the cell body and the axon terminal was similarly accessible to ionophore-mediated influx of $\mathrm{Ca}^{2+}$, and is against

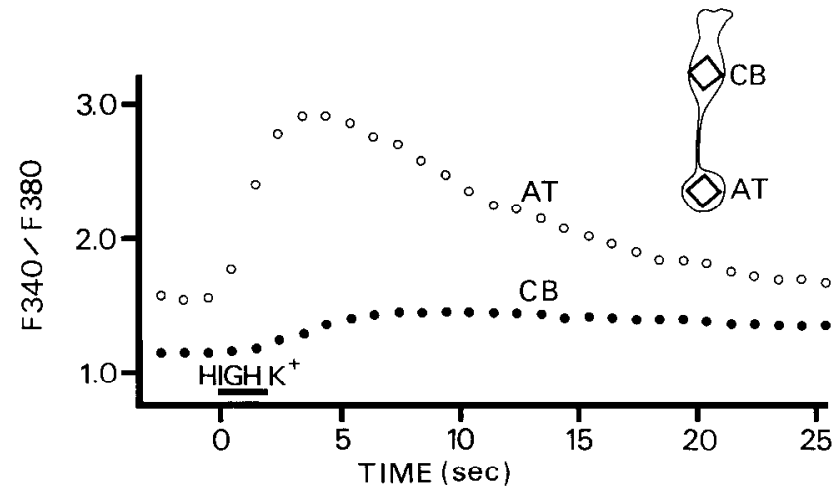

Figure 5. Slow temporal changes of $\left[\mathrm{Ca}^{2+}\right]$ evoked by the application of the high-K' (130 mm) solution. A bipolar cell was incubated with Fura-2/AM $(5 \mu \mathrm{M})$, and pairs of fluorescence images $\left(F_{340}\right.$ and $\left.F_{380}\right)$ were acquired every $1 \mathrm{sec}$. The timing of the high- $\mathrm{K}^{+}$application is shown by the solid bar. Ordinate, Intensity ratio of fluorescence $\left(F_{340} / F_{380}\right)$. Each symbol shows the averaged fluorescence ratio in the square region of the bipolar cell indicated in the inset. $A T$, axon terminal; $C B$, cell body.

the idea that $\mathrm{Ca}^{2+}$ buffering power was substantially different between the axon terminal and the cell body.

It is interesting to note that the bipolar cells, whose axon and axon terminal had been lost during dissociation, showed no increase (three out of six cells) or a slow and small increase (the remaining three cells) of $\left[\mathrm{Ca}^{2+}\right]_{i}$ by a $3 \mathrm{sec}$ puff of the high-K ${ }^{+}$ solution, but showed prominent increase by the application of $\mathrm{Ca}$ ionophores dissolved in the standard solution (not illustrated). Although we are not confident that all of the examined axonless bipolar cells had been equipped with a large axon terminal in the intact tissue, this observation seems to support the hypothesis that the influx of $\mathrm{Ca}^{2+}$ through $\mathrm{Ca}$ channels distributed over the cell body would be a minor component and that the increase of free $\mathrm{Ca}^{2+}$ level at the cell body of intact bipolar cells was mainly due to the diffusion of $\mathrm{Ca}^{2+}$ from the axon terminal.

To control the amount of $\mathrm{Ca}^{2+}$ entry through $\mathrm{Ca}$ channels more quantitatively, bipolar cells were voltage clamped by a patch pipette in the whole-cell recording configuration. The patch pipette was filled with the $\mathrm{Cs}^{+}$solution containing $100 \mu \mathrm{M}$ Fura2. EGTA was not included in the pipette solution to minimize the change of endogenous $\mathrm{Ca}^{2+}$ buffering system.

At the holding potential of $-60 \mathrm{mV},\left[\mathrm{Ca}^{2+}\right]_{i}$ was slightly higher at the axon terminal than at the cell body of the bipolar cell shown in Figure $3 F$. A $500 \mathrm{msec}$ depolarization to $-20 \mathrm{mV}$ evoked $I_{\mathrm{Ca}}$ (Fig. 6, current trace without asterisk) and induced a rapid increase of $\left[\mathrm{Ca}^{2+}\right]_{i}$ at the axon terminal (Figs. $3 G, H ; 6$, trace AT). In a few hundred milliseconds after the onset of the

\footnotetext{
Figure 3. Changes of spatial distribution of $\left[\mathrm{Ca}^{2+}\right]_{i}$ induced by depolarization. $\left[\mathrm{Ca}^{2+}\right]_{i}$ was monitored by using the $\mathrm{Ca}^{2+}$-sensitive dye Fura-2, and the ratio images of $510 \mathrm{~nm}$ fluorescence image induced by $340 \mathrm{~nm}$ excitation wavelength $\left(F_{340}\right)$ to that by $360 \mathrm{~nm}$ excitation wavelength $\left(F_{360}\right)$ are displayed by pseudocolors. $A-E$, Images obtained in a bipolar cell that had been incubated in the solution containing Fura-2/AM (5 $\mu \mathrm{M}) . A$, Image obtained at the resting state. $C B$, cell body; $A X$, axon fiber; $A T$, axon terminal. $B-D$, Images taken during the high-K $\mathrm{K}^{+}(130 \mathrm{mM})$ application. $E$, Image obtained approximately $1 \mathrm{sec}$ after the termination of $3 \mathrm{sec}$ puff of the high- $\mathrm{K}^{+}$solution. The blue region shown by a white arrow is debris. $F-J$, Another bipolar cell was whole-cell voltage clamped, and Fura-2 $(100 \mu \mathrm{M})$ dissolved in the Cs ${ }^{+}$pipette solution (no EGTA) was loaded through the patch pipette. $C B$, cell body; $A T$, axon terminal. The axon fiber was not visible in the ratio images because of low fluorescence intensity. The membrane potential was changed from $-60 \mathrm{mV}(F)$ to $-20 \mathrm{mV}(G$ and $H$ ) for $500 \mathrm{msec}$ in the standard solution. Then, the same cell was microsuperfused with the solution containing nicardipine $(10 \mu \mathrm{M})$ and the membrane potential was changed from $-60 \mathrm{mV}(I)$ to $-20 \mathrm{mV}(J)$ for $500 \mathrm{msec}$. Values at the color calibration bar show the fluorescence ratio $\left(F_{340} / F_{360}\right)$; larger values correspond to higher [Ca $\left.{ }^{2+}\right]_{i}$. The bottom calibration applies to $F-J$
} 


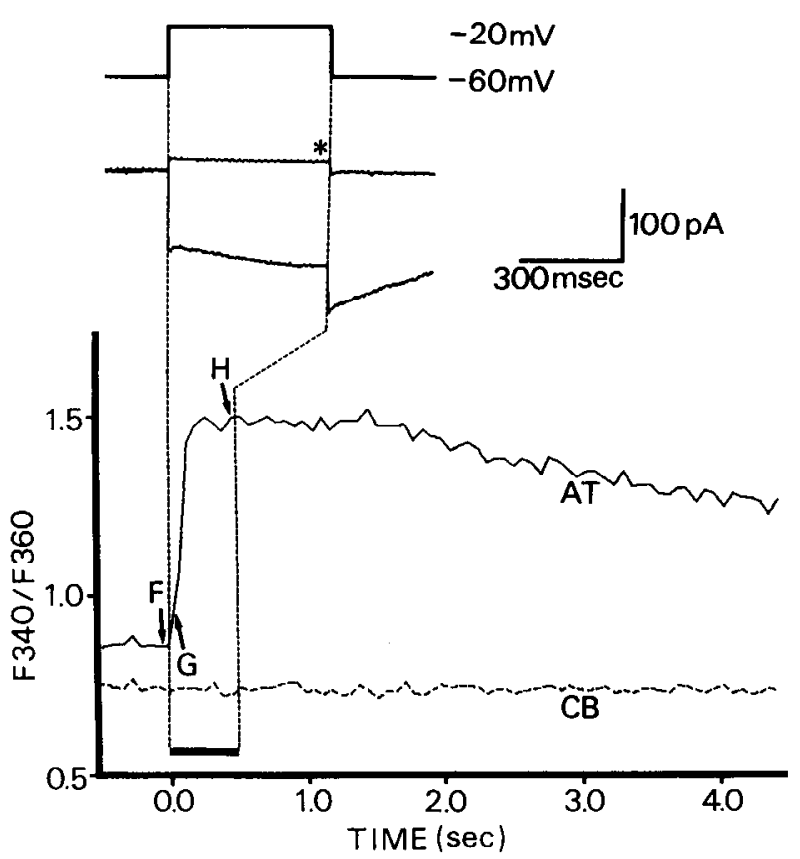

Figure 6. Simultaneous recordings of $I_{\mathrm{Ca}}$ and of temporal changes of $\left[\mathrm{Ca}^{2+}\right]_{i}$ in a voltage-clamped bipolar cell. Patch pipette was filled with the $\mathrm{Cs}^{+}$solution containing Fura-2 $(100 \mu \mathrm{M})$ and no EGTA; same cell and the same cxpcrimental session as in Figure $3 F-H$. The membrane potential was changed from $-60 \mathrm{mV}$ to $-20 \mathrm{mV}$ for $500 \mathrm{msec}$ ( $t o p$ trace and a solid bar near the abscissa). Middle traces are the superimposed current recordings in the presence $\left(^{*}\right)$ and absence of nicardipine $(10 \mu \mathrm{M})$ (low-pass filtered at $250 \mathrm{~Hz})$. Ordinate, Intensity ratio of fluorescence $\left(F_{340} / F_{360}\right)$. Trace $A T$, Averaged fluorescence ratio in the axon terminal. Trace $C B$, Averaged ratio in the cell body. $F-H$ show the time when the corresponding images in Figure 3 were obtained.

depolarization, $\left[\mathrm{Ca}^{2+}\right]_{i}$ at the axon terminal reached a plateau level. The cell was depolarized for only $500 \mathrm{msec}$ but it took a few tens of seconds for the free $\mathrm{Ca}^{2+}$ level to return to the basal value. Similar results were obtained from all bipolar cells examined $(n=36)$. The free $\mathrm{Ca}^{2+}$ level at the cell body did not change ( 27 out of 36 cells; Figs. $3 G, H ; 6$, trace C.B) or only slightly increased with a slow time course (the remaining 9 cells) upon application of the $500 \mathrm{msec}$ depolarization.

The $I_{\mathrm{Ca}}$ was followed by a slow tail current after the cessation of the depolarizing pulse (Fig 6, current trace without asterisk). Both currents were suppressed completely by the extracellular application of $10 \mu \mathrm{M}$ nicardipine (Fig. 6, current trace with astcrisk). The slow tail current was not an artifact due to the escape from voltage clamp for the following reasons. First, the slow tail current did not disappear even when the $R_{s}$ was carefully compensated by the electrical circuitry of the patch-clamp amplifier (see Fig. 10A). Second, the slow tail current became prominent in magnitude and duration as the influx of $\mathrm{Ca}^{2+}$ was increased; a $5 \mathrm{msec}$ voltage pulse (from $-60 \mathrm{mV}$ to $-20 \mathrm{mV}$ ) failed to evoke the slow tail current (see Fig. 8) whereas a 50 msec voltage pulse with the same intensity produced a readily noticeable slow tail current (not illustrated). Third, when the intracellular free $\mathrm{Ca}^{2+}$ was buffered substantially by the introduction of $5 \mathrm{~mm}$ EGTA via patch pipette, it was difficult to evoke the slow tail current even with a $500 \mathrm{msec}$ voltage pulse of the same intensity (see Fig. $10 B$ ). It is therefore very likely that the slow tail current was caused mainly by the activation of a $\mathrm{Ca}^{2+}$-mediated process(es). The activation of such a pro-

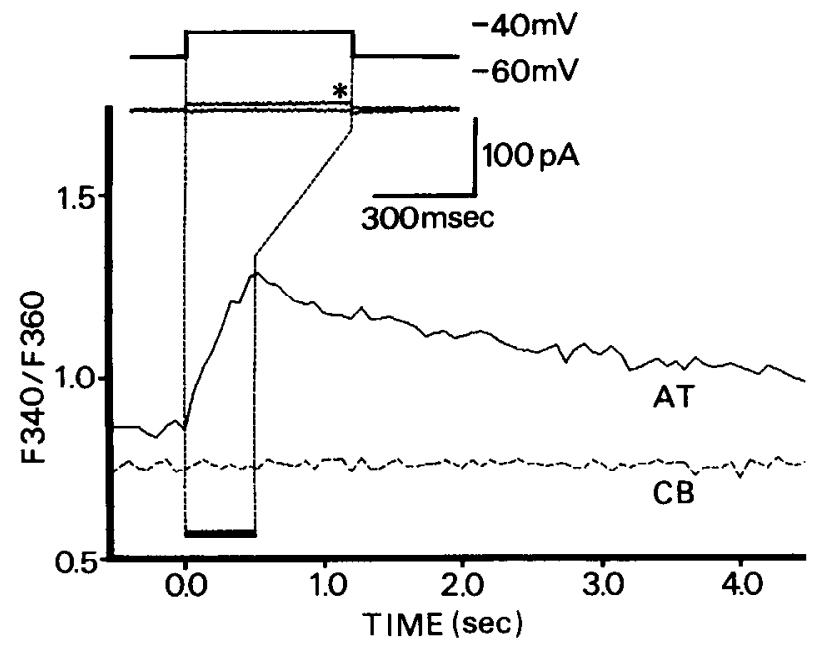

Figure 7. Simultaneous recordings of $I_{\mathrm{Ca}}$ and of temporal changes of $\left[\mathrm{Ca}^{2+}\right]_{i}$. The membrane potential was shifted from $-60 \mathrm{mV}$ to $-40 \mathrm{mV}$ for 500 msec: superimposed current recordings in the presence $\left(^{*}\right)$ and absence of nicardipine $(10 \mu \mathrm{M})$, low-pass filtered at $250 \mathrm{~Hz}$. Data were obtained from the same cell shown in Figure 6. $A T$, axon terminal; $C B$, cell body.

cess(es) would have induced the apparent gradual increase of $I_{\mathrm{Ca}}$ during the depolarization (Fig. 6). The properties of the $\mathrm{Ca}^{2+}$. mediated process(es) were not analyzed further for this article.

One may argue that the sensitivity of the $\mathrm{Ca}^{2+}$ imaging system would be too low to detect the rise of $\left[\mathrm{Ca}^{21}\right]_{i}$ at the cell body. To examine this possibility the amount of $\mathrm{Ca}^{2+}$ entry was controlled by changing the amplitude and duration of depolarizing pulses. When the membrane potential of the same bipolar cell shown in Figure 6 was depolarized to $-40 \mathrm{mV}$ for $500 \mathrm{msec}$, the influx of $\mathrm{Ca}^{2+}$ was approximately one-tenth of that induced by the depolarizing pulse to $-20 \mathrm{mV}$ (Fig. 7, superimposed current traces). The free $\mathrm{Ca}^{2+}$ level increased prominently at the axon terminal, although the change was slower and smaller (Fig. 7 , trace $\mathrm{AT}$ ) than that induccd by the depolarization to -20 $\mathrm{mV}$ (see Fig. 6). On the other hand, the free $\mathrm{Ca}^{2+}$ did not increase at all at the cell body (Fig. 7 , trace CB). Similar results were obtained from all cells examined $(n=16)$.

When the duration of the voltage pulse (from $-60 \mathrm{mV}$ to $-20 \mathrm{mV}$ ) was decreased from 500 to $50 \mathrm{msec}$, the free $\mathrm{Ca}^{2+}$ level at the axon terminal increased with a similar rate but the peak level was lower than that evoked by the $500 \mathrm{msec}$ pulse (not illustrated; 15 out of 15 cells examined). Even when the duration was reduced to $5 \mathrm{msec}$, we could observe a small but detectable increase of free $\mathrm{Ca}^{2+}$ level at the axon terminal (Fig. 8, same cell shown in Figs. 6,7 ) in 18 out of 23 cells examined. It is evident that our $\mathrm{Ca}$ imaging system was sensitive enough to detect the changes of $\left[\mathrm{Ca}^{2+}\right]_{i}$ at the axon terminal even when the $\mathrm{Ca}^{2+}$ entry was reduced to approximately $1 \%$ of that induced by the $500 \mathrm{msec}$ depolarization to $-20 \mathrm{mV}$.

To examine whether the increase of $\left[\mathrm{Ca}^{2+}\right]_{i}$ was caused by the influx of $\mathrm{Ca}^{2+}$ through dihydropyridine-sensitive $\mathrm{Ca}$ channels, the $500 \mathrm{msec}$ depolarizing pulse to $-20 \mathrm{mV}$ was applied in the presence of nicardipine, a light-resistant derivative of dihydropyridines. Nicardipine ( $10 \mu \mathrm{M})$ suppressed $I_{\mathrm{Ca}}$ almost completely (Fig. 9, current trace), and $\left[\mathrm{Ca}^{2+}\right]_{i}$ did not change significantly either at the axon terminal or at the cell body (Figs. 3J; 9, traces AT, CB). When nifedipine, a photolabile derivative of dihydropyridines, was used as a $\mathrm{Ca}$ channel blocker, $I_{\mathrm{Ca}}$ was almost 


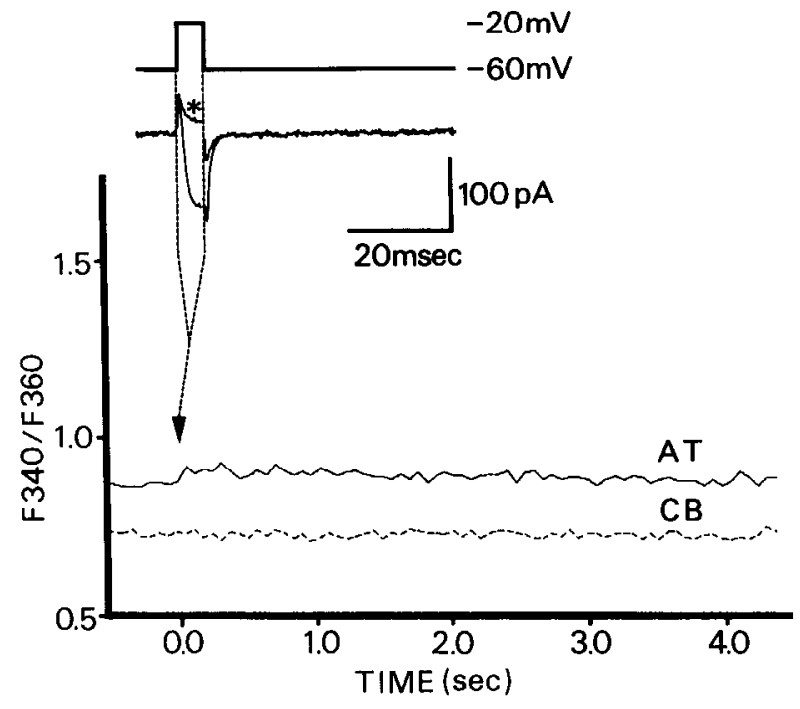

Figure 8. Simultaneous recordings of $I_{\mathrm{Ca}}$ and of temporal changes of $\left[\mathrm{Ca}^{2+}\right]_{i}$. The membrane potential was shifted from $-60 \mathrm{mV}$ to $-20 \mathrm{mV}$ for $5 \mathrm{msec}$ : superimposed current recordings in the presence $\left(^{*}\right)$ and absence of nicardipine $(10 \mu \mathrm{M})$, low-pass filtered at $5 \mathrm{kHz}$. Data were obtained from the same cell shown in Figures 6 and 7. $A T$, axon terminal; $C B$, cell body.

completely suppressed in the dark, but it was unblocked partially by the illumination with the UV light that was required for Fura-2 excitation, resulting in a weak increase in free $\mathrm{Ca}^{2+}$ level at the axon terminal $(n=4) . \mathrm{Co}^{2+}$, a nonselective $\mathrm{Ca}$ channel blocker, suppressed completely both $I_{\mathrm{Ca}}$ and the increase of $\left[\mathrm{Ca}^{2+}\right]_{i}$, reversibly $(n-3)$. It is concluded that the $\mathrm{Ca}^{2+}$ entry occurred through dihydropyridine-sensitive $\mathrm{Ca}$ channels and that a localized increase of $\left[\mathrm{Ca}^{2+}\right]_{i}$ was evoked at the axon terminal when bipolar cells were depolarized by a relatively short voltage pulse.

The localized increase of $\left[\mathrm{Ca}^{2+}\right]_{i}$ at the axon terminal region strongly suggested that the entered $\mathrm{Ca}^{2+}$ must exert important physiological functions at the axon terminal region. Due to the lack of adequate information about the regulatory systems of intracellular free $\mathrm{Ca}^{2+}$ in bipolar cells, the spatial distribution of Ca channels over the cell membrane could not be deduced directly from the measurement of $\left[\mathrm{Ca}^{2+}\right]_{\text {, signals (see Discus- }}$ sion). However, a simple interpretation of the present results would be to assume that most of $\mathrm{Ca}$ channels are localized to the axon terminal region.

In the experiments described above, only $100 \mu \mathrm{M}$ Fura- 2 served as a $\mathrm{Ca}^{2+}$ buffer in the pipette solution. It was not certain that $\left[\mathrm{Ca}^{2+}\right]_{i}$ of bipolar cells under such recording condition was within a physiological range. Thus, we carried out the experiments in which the pipette solution contained 1 or $5 \mathrm{~mm}$ EGTA in addition to $100 \mu \mathrm{M}$ Fura-2. When bipolar cells were depolarized from $-60 \mathrm{mV}$ to $-20 \mathrm{mV}$ for $500 \mathrm{msec}$, the increase of free $\mathrm{Ca}^{2+}$ level was restricted to the axon terminal in 10 out of 13 bipolar cells (not illustrated). In the remaining three cells a prominent increase of $\left[\mathrm{Ca}^{2+}\right]_{i}$ was observed at the axon terminal, and a small and slow increase at the cell body. When the influx of $\mathrm{Ca}^{2+}$ was reduced to one-tenth by decreasing the duration or intensity of voltage pulses, the increase of $\left[\mathrm{Ca}^{2+}\right]_{i}$ was confined to the axon terminal region ( $n=5$ ) (not illustrated). These observations favored the hypothesis of localization of Ca channels in the axon terminal because the introduction of a high concentration of diffusible $\mathrm{Ca}^{2+}$ buffer (i.e., EGTA) into the cells

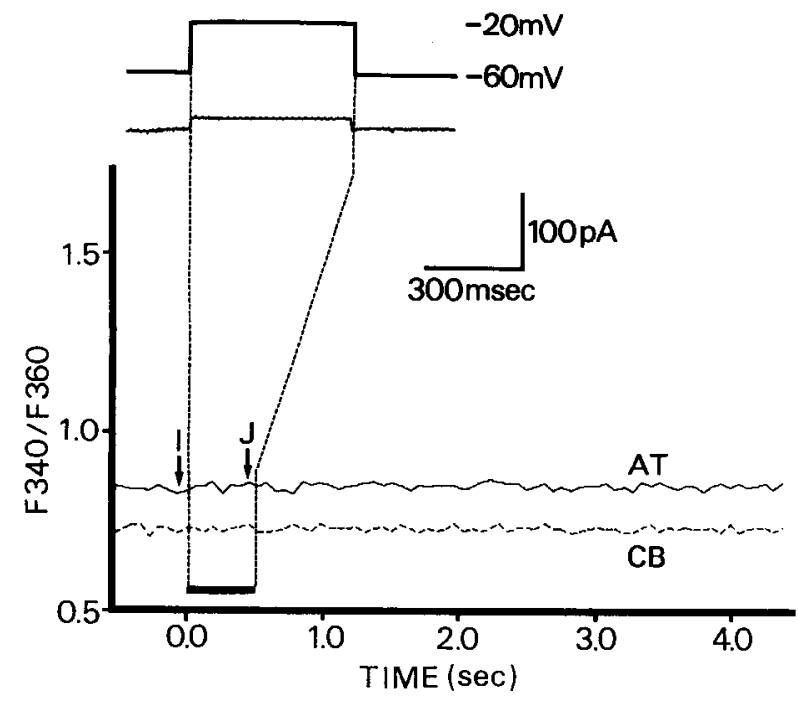

Figure 9. Simultaneous recordings of the membrane current and temporal changes of $\left[\mathrm{Ca}^{2+}\right]_{i}$ in the presence of nicardipine $(10 \mu \mathrm{M})$; same cell as in Figures 6-8 and the same experimental session as in Figure $3, I$ and $J$. The depolarizing pulse was from $-60 \mathrm{mV}$ to $-20 \mathrm{mV}$ for $500 \mathrm{msec}$ (top trace and a solid bar). Ordinate, Intensity ratio of fluorescence $\left(F_{340} / F_{36 n}\right)$. Trace $A T$, Averaged fluorescence ratio in the axon terminal. Trace $C B$, Averaged ratio in the cell body. $I$ and $J$ show the time when the corresponding images in Figure 3 were taken.

should have attenuated possible heterogeneities in the intrinsic $\mathrm{Ca}^{2+}$ buffering power.

The hypothesis of Ca channel localization in the axon terminal scemcd to be also supportcd by the following obscrvations. The amplitude of $I_{\mathrm{Ca}}$ recorded from the bipolar cells (subtype unidentified), whose axon and axon terminal had been lost during the dissociation, was extremely small (less than 2 pA current was induced by depolarization to $-20 \mathrm{mV} ; n=17 ; 0-5 \mathrm{~mm}$ EGTA). We also examined changes of $\left[\mathrm{Ca}^{2+}\right]_{i}$ by using the axonless bipolar cells, which were whole-cell voltage clamped by a palch pipette filled with $100 \mu \mathrm{M}$ Fura-2 and no EGTA. The $500 \mathrm{msec}$ depolarization to $-20 \mathrm{mV}$ did not increase the free $\mathrm{Ca}^{2+}$ level in seven out of nine cells (not illustrated). The remaining two cells showed a slight increase of $\left[\mathrm{Ca}^{2+}\right]_{i}$.

\section{Transmitter release and dihydropyridine-sensitive Ca current}

The axon terminal of bipolar cells is the specialized region from which neurotransmitter is released. We investigated whether the endogenous neurotransmitter is released by the activation of dihydropyridine-sensitive $I_{\mathrm{Ca}}$ of bipolar cells. The ncurotransmitter of bipolar cells is assumed to be an excitatory amino acid, very probably glutamate (the presence of glutamate immunoreactivity: Ehinger et al., 1988; Marc et al., 1990; the release of excitatory amino acids: Tachibana and Okada, 1991; the postsynaptic effects: Slaughter and Miller, 1983; Bloomfield and Dowling, 1985; Kato et al., 1985; Lukasiewicz and McReynolds, 1985; Barnes and Werblin, 1987; Aizenman et al., 1988).

The axon terminal of a goldfish bipolar cell was closely apposed to the cell body of a catfish horizontal cell, which served as a detector of excitatory amino acids. When the bipolar cell was depolarized from $-55 \mathrm{mV}$ to $-20 \mathrm{mV}$ for $300 \mathrm{msec}$, an inward $I_{\mathrm{Ca}}$ was recorded from the bipolar cell and an outward current from the horizontal cell voltage clamped at $+30 \mathrm{mV}$ (Fig. 10 Aa). As demonstrated in previous work (Tachibana and Okada, 1991), the outward current recorded from the apposed 


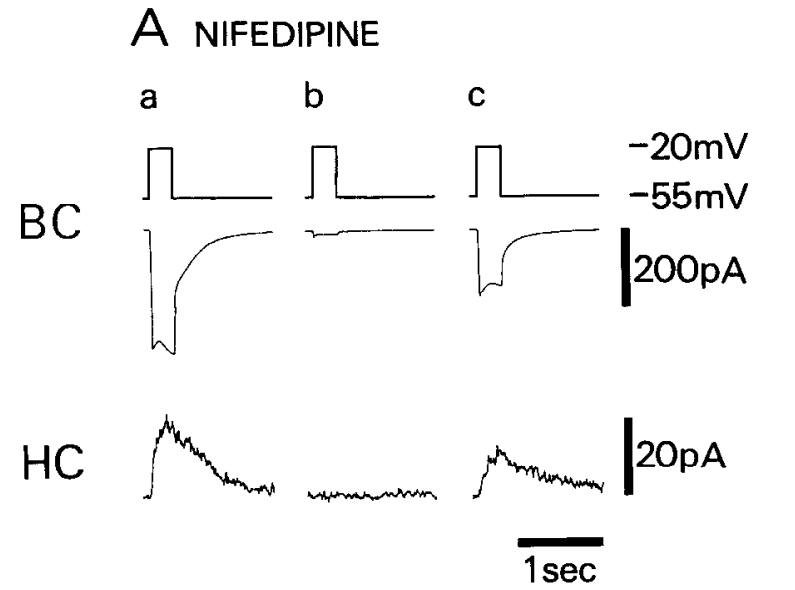

\section{B $\omega$-CONOTOXIN}

a $\quad b$
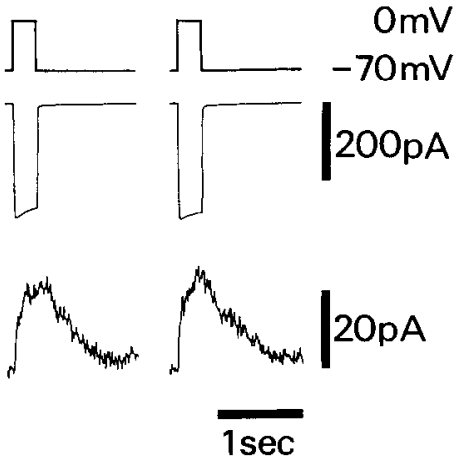

Figure 10. Effects of nifedipine and $\omega$-conotoxin on $I_{\mathrm{Ca}}$ of a goldfish bipolar cell and on the transmitter-induced response recorded from a catfish horizontal cell closely apposed to the axon terminal of the bipolar cell. $A$, A depolarizing pulse ( $300 \mathrm{msec}$ pulse from $-55 \mathrm{mV}$ to $-20 \mathrm{mV}$; top trace) applied to the bipolar cell $(B C)$ evoked $I_{C a}$ in the bipolar cell (middle trace) and an outward current (transmitter-induced response) in the apposed horizontal cell (IIC) voltage clamped at $+30 \mathrm{mV}$ (bottom trace). a, The pair of cells was microsuperfused with the standard solution supplemented with glycine $(10 \mu \mathrm{M}) . b$, Nifedipine $(30 \mu \mathrm{M})$ was added to the solution. $c$, After the washout of nifedipine. Patch pipettes were filled with the $\mathrm{Cs}^{+}$solution containing BAPTA $(1 \mathrm{~mm})$. In the recordings from the bipolar cell, $R_{s}$ compensation was turned on (approximately $50 \%$ compensation; $R_{s}=23 \mathrm{M} \Omega$ ). Currents were low-pass filtered at $100 \mathrm{~Hz}$. $B$, Recordings from another cell pair. A bipolar cell was depolarized from $-70 \mathrm{mV}$ to $0 \mathrm{mV}$ for $300 \mathrm{msec}$, before $(a)$ and during $(b)$ the application of $\omega$-conotoxin $(1 \mu \mathrm{M})$. The holding potential of the apposed horizontal cell was $+40 \mathrm{mV}$. Glycine $(10 \mu \mathrm{M})$ was always added to the solutions. Patch pipettes were filled with the Cs ${ }^{+}$solution containing EGTA (5 mM). The series resistance was not compensated. Currents were low-pass filtered at $100 \mathrm{~Hz}$.

horizontal cells was induced by an endogenous excitatory amino acid transmitter released from the axon terminal of bipolar cells (transmitter-induced current).

When the solution containing nifedipine $(30 \mu \mathrm{M})$ was ejected to the same pair of cells from the $Y$-tube microflow system, $I_{C a}$ was strongly blocked and, at the same time, the transmitterinduced current was almost completely suppressed (Fig. 10A $\mathrm{A}$ ). After the washout of nifedipine, both $I_{\mathrm{Ca}}$ and the transmitterinduced current recovered partially (Fig. 10 Ac). On the other hand, the application of $\omega$-conotoxin $(1 \mu \mathrm{M})$ did not cause detectable changes either in $I_{\mathrm{Ca}}$ or in the transmitter-induced cur-

A CONTROL

B BAY K 8644

WASHOUT

$\mathrm{BC}$
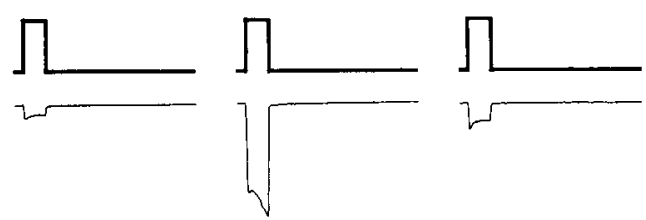

$-35 \mathrm{mV}$

$-70 \mathrm{mV}$ 200pA

$\mathrm{HC}$

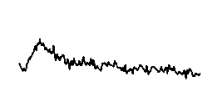

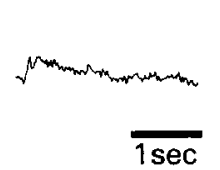

$20 \mathrm{pA}$
Figure 11. Effects of Bay $\mathrm{K} 8644$ on $I_{\mathrm{Ca}}$ of a bipolar cell and on the transmitter-induced response of a closely apposed horizontal cell. A depularization ( $300 \mathrm{msec}$ pulse from $-70 \mathrm{mV}$ to $-35 \mathrm{mV}$; top traces) applied to a bipolar cell $(B C)$ evoked $I_{\mathrm{Ca}}$ in the bipolar cell (middle traces) and the transmitter-induced current in the horizontal cell $(H C)$, voltage clamped at $+40 \mathrm{mV}$ (bottom traces). $A$, Control condition; $B$, in the presence of Bay K $8644(0.2 \mu \mathrm{M})$; $C$, after the washout of Bay $\mathrm{K}$ 8644 . Glycine $(10 \mu \mathrm{M})$ was present in all the solutions applied to the preparation. Patch pipettes were filled with the $\mathrm{Cs}^{+}$solution containing EGTA (5 mM). Currents were low-pass filtered at $100 \mathrm{~Hz}$. rent [Fig. 10B, absence $(a)$ and presence $(b)$ of $\omega$-conotoxin]. The glutamate-induced responses recorded from horizontal cells were not affected either by nifedipine $(30 \mu \mathrm{M}, n=3)$ or by $\omega$-conotoxin $(2 \mu \mathrm{M}, n=4)$. Therefore, these results prove that the dihydropyridine-sensitive $\mathrm{Ca}$ current was responsible for the release of an endogenous excitatory amino acid transmitter from goldfish on-type bipolar cells.

This conclusion was further confirmed by the evidence that Bay K 8644 increased the transmitter-induced current (Fig. 11). A weak depolarizing pulse (from $-70 \mathrm{mV}$ to $-35 \mathrm{mV}$ ) applied to a bipolar cell evoked a small $I_{\mathrm{Ca}}$ in the bipolar cell, and a small but detectablc transmitter-induced current in the apposed horizontal cell (Fig. 11A). Application of $0.2 \mu \mathrm{M}$ Bay K 8644 potentiated $I_{\mathrm{Ca}}$ and increased the transmitter-induced current (Fig. $11 B$ ). The effect of Bay K 8644 was reversible (Fig. 11C). Bay K 8644 itself did not affect the glutamate-induced responses recorded from horizontal cells $(n=8)$.

It should also be noted in Figure 11 that the potentiation of $I_{\mathrm{Ca}}$ induced by Bay K 8644 was severalfold, whereas the increase in the transmitter-induced current was only twofold. This difference may be explained by the nonlinear relationship between the influx of $\mathrm{Ca}^{2+}$ and the neurotransmitter release (see Tachibana and Okada, 1991; detailed analysis in preparation).

It is interesting to note that, in two instances, we could carry out a pair experiment using as presynaptic element the axon terminal detached from the cell body of bipolar cells; the activation of $I_{\mathrm{Ca}}$ (maximal amplitude $>100 \mathrm{pA}$ ) in the axon terminal cvoked the rclcasc of cxcitatory amino acid transmitter, and both currents were blocked by nifedipine (not illustrated).

\section{Discussion}

The present study demonstrates that the plasma membrane of goldfish on-type bipolar cells is endowed with dihydropyridinesensitive Ca channels, and that the activation of these channels induces a rapid increase of $\left[\mathrm{Ca}^{2+}\right]_{i}$ at the axon terminal region, resulting in the release of an excitatory amino acid transmitter. 


\section{Distribution of dihydropyridine-sensitive Ca channels}

In our Fura-2 imaging experiments, bipolar cells were depolarized for short periods (the puff of high-K+ ${ }^{+}$solution, less than 3 $\mathrm{sec}$; the voltage pulses, less than $500 \mathrm{msec}$ ) to activate $I_{\mathrm{Ca}}$, and it was found that the increase of $\left[\mathrm{Ca}^{2+}\right]_{i}$ at the axon terminal was much faster and larger than that at the cell body. Especially when the Fura- 2 imaging was carried out under voltage clamp, the increase of $\left[\mathrm{Ca}^{2+}\right]$, was almost confined to the axon terminal region (Figs. 6-8). In a recent report Heidelberger and Matthews (1992) used the same preparation as ours and measured the changes of $\left[\mathrm{Ca}^{2+}\right]$, in response to the depolarization of bipolar cells incubated with Fura-2/AM. They reported a substantial increase of $\left[\mathrm{Ca}^{2+}\right]$, at the cell body as well as at the axon terminal. It is conceivable that this difference in the experimental results reflects a real difference between the physiological properties of goldfish bipolar cells in the two experimental conditions, resulting, for instance, from subtle differences in the dissociation procedures or from recording techniques. However, it seems possible to interpret the experimental observations about the magnitude of $\left[\mathrm{Ca}^{2+}\right]_{i}$ at the cell body as follows. Since in their experiments bipolar cells were depolarized for long periods ( $>30$ sec) by the bath application of high- $\mathrm{K}^{+}$solution, there would be enough time for $\mathrm{Ca}^{2+}$ that entered into the axon terminal to diffuse through the axon fiber, resulting in a large increase of $\left[\mathrm{Ca}^{2+}\right]_{i}$ at the cell body. Furthermore, since $\left[\mathrm{Ca}^{2+}\right]_{i}$ was sampled at exclusively two regions of the cell, in different times and using a photomultiplier tube with a large optical aperture, it was not possible to detect the progression of the $\mathrm{Ca}^{2+}$ signal from the axon terminal to the soma along the axon fiber, which was clearly evident in our images (see Fig. 3).

The localized increase of $\left[\mathrm{Ca}^{2+}\right]_{i}$ at the axon terminal suggests that $\mathrm{Ca}^{2+}$, entered through dihydropyridine-sensitive $\mathrm{Ca}$ channels, must play an immediate function at the axon terminal and perhaps a slow function, if any, at the cell body. In fact, the present study demonstrated that the excitatory amino acid transmitter was released promptly from the axon terminal in response to the activation of $I_{\mathrm{Ca}}$ (Figs. 10,11).

At first the localized increase of $\left[\mathrm{Ca}^{2+}\right]_{i}$ in the axon terminal observed in our experiments would suggest a predominant localization of $\mathrm{Ca}$ channels in the axon terminal. However, the magnitude and spatiotemporal distribution of the $\left[\mathrm{Ca}^{2+}\right]_{i}$ signals are the consequence of the interaction between various cellular $\mathrm{Ca}^{2+}$ sources $\left(\mathrm{Ca}^{2+}\right.$ entry through $\mathrm{Ca}$ channels and release from intracellular $\mathrm{Ca}^{2+}$ store sites) and $\mathrm{Ca}^{2+}$ removal mechanisms ( $\mathrm{Ca}^{2+}$ binding proteins, $\mathrm{Ca}^{2+}$ pumps, and $\mathrm{Na}^{+}-\mathrm{Ca}^{2+}$ exchanger) (reviewed in Blaustein, 1988; see also Neher and Augustine, 1992). It seems, thus, difficult to estimate the spatial distribution of Ca channels over the bipolar cell membrane based uniquely upon the $\left[\mathrm{Ca}^{2+}\right]_{i}$ signals. However, the present experiments suggested that the endogenous $\mathrm{Ca}^{2+}$ buffering power is not substantially different between the axon terminal and the cell body because the increase of $\left[\mathrm{Ca}^{2+}\right]_{i}$ was always observed predominantly at the axon terminal region even when bipolar cells were filled with a high concentration of the diffusible $\mathrm{Ca}^{2+}$ buffer EGTA, and because the application of $\mathrm{Ca}^{2+}$ ionophores induced a similar increase of $\left[\mathrm{Ca}^{2+}\right]_{i}$ at both regions. If we assume that intracellular free $\mathrm{Ca}^{2+}$ level is regulated similarly at the two regions, and that, after entering, free $\mathrm{Ca}^{2+}$ distributes rather promptly and evenly in the cytoplasm of each region (consider that the volume of cell body is about three limes larger than that of axon terminal), we could roughly estimate the distri- bution of $\mathrm{Ca}$ channels. Under such simplified conditions, approximately $97 \%$ of the total $I_{\mathrm{Ca}}$ would enter into the axon terminal region in order to explain our results, namely, that we could detect the increase of $\left[\mathrm{Ca}^{2+}\right]_{i}$ at the axon terminal induced by a $5 \mathrm{msec}$ depolarization (Fig. 8 ) but we failed to detect the increase at the cell body even when the same bipolar cell was depolarized for $500 \mathrm{msec}$ (Fig. 6). Our Fura-2 fluorescence measurement system would have detected the changes of $\left[\mathrm{Ca}^{2+}\right]_{i}$ at the cell body if the influx of $\mathrm{Ca}^{2+}$ into the cell body was more than $5 \%$ of the total $I_{\mathrm{Ca}}$.

The above estimation was supported by our electrophysiological observation that the maximal amplitude of $I_{\mathrm{Ca}}$ recorded from the axonless bipolar cells was much smaller (a few picoamperes at most) than that recorded from bipolar cells with intact axon terminal or from detached axon terminals $(>100$ pA). Heidelberger and Matthews (1992) also compared the amplitude of $I_{\mathrm{Ca}}$ before and during the puff application of $\mathrm{Ca}^{2+}$ or $\mathrm{Cd}^{2+}$ to the different regions of a bipolar cell, and found evidence supporting their observation that approximately $40 \%$ of the total $I_{\text {Ca }}$ would flow into the cell body region. However, with this experimental protocol it seems difficult to be sure that the rapidly diffusible ions could affect the Ca channels within a precisely restricted region at a controlled concentration.

In conclusion, our results support the idea that the dihydropyridine-sensitive $\mathrm{Ca}$ channels are highly localized in the axon terminal region. In other preparations it has been shown that the Ca channels involved in the release of neurotransmitter are localized exclusively at the active zones of the presynaptic membrane (Robitaille et al., 1990; Cohen et al., 1991; see also LasserRoss et al., 1991).

\section{Voltage dependence of the Ca current}

With reference to the dihydropyridine-sensitive Ca current described in most other preparations, $I_{\mathrm{Ca}}$ of goldfish bipolar cells has an activation curve shifted to relatively negative potentials. In this respect, however, it is similar to the slow type of highvoltage-activated $I_{\mathrm{Ca}}$ described by Fedulova et al. (1985) in dorsal root ganglion neurons of newborn rats, and to the nitrendipine-sensitive $I_{\mathrm{Ca}}$ found in cones of the retina of different species (lizard, Maricq and Korenbrot, 1988; salamander, Barnes and Hille, 1989; turtle, Lasater and Witkovsky, 1991; chicken, Gleason et al., 1992). As already pointed out for salamander cones (Barnes and Hille, 1989), the negative shift of $I_{\mathrm{Ca}}$ in goldfish bipolar cells sets the activation threshold of this current (approximately $-45 \mathrm{mV}$ ) near the resting potential (approximately $-40 \mathrm{mV}$ ) of these neurons in the intact retina (Saito and Kujiraoka, 1982). Photoresponses of bipolar cells in situ cover the potential range between approximately -60 and $-20 \mathrm{mV}$ (Ashmore and Falk, 1980). The transmission of bipolar cell signals to postsynaptic cells may be clipped at potential more negative than the activation threshold of $I_{\mathrm{Ca}}$ (see Attwell et al., 1987). Another possibility is that signals may be transmitted to the postsynaptic cells by changing the balance between the release and uptake of neurotransmitter at the synaptic cleft (see Discussion in Tachibana and Okada, 1991). This problem should be solved by simultaneous recording of responses from pre- and postsynaptic neurons in the retinal slice preparation.

\section{Functional specificity of Ca channels}

The present study demonstrated that the release of "fast" neurotransmitter (very likely glutamate) from goldfish on-type bipolar cells depends critically on the activation of the dihydro- 
pyridine-sensitive $I_{\text {ca. }}$. This conclusion contrasts with the hypothesis that the release of "fast" neurotransmitter is triggered by the activation of $\omega$-conotoxin-sensitive $I_{\text {Ca }}$, while dihydropyridine-sensitive $I_{C \mathrm{C}}$ is involved in the release of "slow" neurotransmitter (Miller, 1987; Hirning et al., 1988). However, most of evidence leading to this hypothesis was indirect and was obtained in experiments in which simultaneous monitoring of $I_{\mathrm{Ca}}$ and the release of neurotransmitter was not carried out. In synaptosome preparations, the involvement of subtypes of presynaptic $I_{C \text { a }}$ has been assumed on the basis of pharmacological studies, which do not lead to straightforward interpretation (Reynolds et al., 1986; Woodward and Leslie, 1986).

The hypothesis of a generalized involvement of $\omega$-conotoxinsensitive channels in the release of "fast" neurotransmitter is also contradicted by other observations indicating that the rclease of the same neurotransmitter from the same type of neurons may be mediated by $I_{C a}$ having different pharmacological selectivity in different species. For instance, $\omega$-conotoxin blocks neuromuscular transmission in the frog but not in the mouse and chicken (Kerr and Yoshikami, 1984; Yoshikami et al., 1989; De Luca et al., 1991). It is likely that the release of neurotransmitter is triggered by the influx of $\mathrm{Ca}^{2+}$ to presynaptic terminals through Ca channels irrespective of their subtypes, and the different presynaptic terminals may have different $\mathrm{Ca}$ channels appropriate to their functional requirements, differing for what concerns the activation range, the activation and inactivation kinetics, the single-channel conductance, modulation properties, and other functional characteristics.

\section{References}

Aizenman E, Frosch MP, Lipton SA (1988) Responses mediated by amino acid receptors in solitary retinal ganglion cells from rat. $\mathbf{J}$ Physiol (Lond) 396:75-91.

Aosaki T, Kasai H (1989) Characterization of two kinds of highvoltage-activated $\mathrm{Ca}$-channel currents in chick sensory neurons. Differential sensitivity to dihydropyridines and $\omega$-conotoxin GVIA. Pfluegers Arch 414:150-156.

Armstrong CM, Matteson DR (1985) Two distinct populations of calcium channels in a clonal line of pituitary cells. Science $227: 65-$ 67.

Ashmore JF, Falk G (1980) Responses of rod bipolar cells in the darkadapted retina of the dogfish, Scyliorhinus canicula. J Physiol (Lond) 300:115-150.

Attwell D, Borges S, Wu SM, Wilson M (1987) Signal clipping by the rod output synapse. Nature 328:522-524

Augustine GJ, Charlton MP, Smith SJ (1985) Calcium entry and transmitter release at voltage-clamped nerve terminals of squid. J Physiol (Lond) 369:163-181.

Augustine GJ, Charlton MP, Smith SJ (1987) Calcium action in synaptic transmitter release. Annu Rev Neurosci 10:633-693.

Barnes S, Hille B (1989) Ionic channels of the inner segment of tiger salamander cone photoreceptors. J Gen Physiol 94:719-743.

Barnes S, Werblin F (1987) Direct excitatory and lateral inhibitory synaptic inputs to amacrine cells in the tiger salamander retina. Brain Res 406:233-237.

Bean BP (1984) Nitrendipine block of cardiac calcium channels: highaffinity binding to the inactivated state. Proc Natl Acad Sci USA 81: 6388-6392.

Bean BP (1989) Classes of calcium channels in vertebrate cells. Annu Rev Physiol 51:367-384.

Blaustein MP (1988) Calcium transport and buffering in neurons. Trends Neurosci 11:438-443.

Bloomfield SA, Dowling JE (1985) Roles of aspartate and glutamate in synaptic transmission in rabbit retina. II. Inner plexiform layer. $\mathrm{J}$ Neurophysiol 53:714-725.

Carbone E, Lux HD (1984) A low voltage-activatcd, fully inactivating Ca channel in vertebrate sensory neurones. Nature 310:501-502.
Cardone E, Swandulla D (1989) Neuronal channels: kinetics, blockade, and modulation. Prog Biophys Mol Biol 54:31-58.

Charlton MP, Augustine GJ (1990) Classification of presynaptic calcium channels at the squid giant synapse: neither T-, L- nor N-type. Brain Res 525:133-139.

Cohen MW, Jones OT, Angelides KJ (1991) Distribution of $\mathrm{Ca}^{2+}$ channels on frog motor nerve terminals revealed by fluorescent $\omega$-conotoxin. J Neurosci 11:1032-1039.

De Luca A, Rand MJ, Reid JJ, Story DF (1991) Differential sensitivities of avian and mammalian neuromuscular junctions to inhibition of cholinergic transmission by $\omega$-conotoxin GVIA. Toxicon 29:311320.

Ehinger B, Ottersen OP, Storm-Mathisen J, Dowling JE (1988) Bipolar cells in the turtle retina are strongly immunoreactive for glutamate. Proc Natl Acad Sci USA 85:8321-8325.

Fedulova SA, Kostyuk PG, Veselovsky NS (1985) Two types of calcium channels in the somatic membrane of new-born rat dorsal root ganglion neurones. J Physiol (Lond) 359:431-446.

Fox AP, Nowycky MC, Tsien RW (1987) Kinetic and pharmacological properties distinguishing three types of calcium currents in chick sensory neurones. J Physiol (Lond) 394:149-172.

Gleason E, Mobbs P, Nuccitelli R, Wilson M (1992) Development of functional calcium channels in cultured avian photoreceptors. Vis Neurosci 8:315-327.

Grynkiewicz G, Poenie M, Tsien RW (1985) A new generation of $\mathrm{Ca}^{2+}$ indicators with greatly improved fluorescence properties. J Biol Chem 260:3440-3450.

Hagiwara S, Ozawa S, Sand O (1975) Voltage clamp analysis of two inward current mechanisms in the egg cell membrane of a starfish. J Gen Physiol 65:617-644.

Hamill OP, Marty A, Neher E, Sakmann B, Sigworth FJ (1981) Improved patch-clamp techniques for high-resolution current recording from cell and cell-free membrane patches. Pfluegers Arch 391:85100.

Heidelberger R, Matthews $G$ (1992) Calcium influx and calcium current in single synaptic terminals of goldfish retinal bipolar neurons. J Physiol (Lond) 447:235-256.

Hirning LD, Fox AP, McCleskey EW, Olivera BM, Thayer SA, Miller RJ, Tsien RW (1988) Dominant role of $\mathrm{N}$-type $\mathrm{Ca}^{2+}$ channels in evoked release of norepinephrine from sympathetic neurons. Science 239:57-61.

Ishida AT, Stell WK, Lightfoot DA (1980) Rod and cone inputs to bipolar cells in goldfish retina. J Comp Neurol 191:315-335.

Kaneko A, Tachibana M (1985) A voltage-clamp analysis of membrane currents in solitary bipolar cells dissociated from Carassius auratus. J Physiol (Lond) 358:131-152.

Kaneko A, Pinto LH, Tachibana M (1989) Transient calcium current of retinal bipolar cells of the mouse. J Physiol (Lond) 410:613-629.

Kasai H, Aosaki T, Fukuda J (1987) Presynaptic Ca-antagonist $\omega$-conotoxin irreversibly blocks $\mathrm{N}$-type $\mathrm{Ca}$-channels in chick sensory neurons. Neurosci Res 4:228-235.

Kato S, Teranishi T, Negishi K (1985) L-Glutamate depolarizes onoff transient type of amacrine cells in the carp retina: an ionophoretic study. Brain Res 329:390-394.

Katz B, Miledi R (1969) Tetrodotoxin-resistant electric activity in presynaptic terminals. J Physiol (Lond) 203:459-487.

Kerr LM, Yoshikami D (1984) A venom peptide with a novel presynaptic blocking action. Nature 308:282-284.

Lasater EM, Witkovsky P (1991) The calcium current of turtle cone photorcceptor terminals. Neurosci Res [Suppl] 15:S165-S173.

Lasser-Ross N, Callaway JC, Stuart AE, Ross WN (1991) Calcium dynamics in the presynaptic terminal of barnacle photoreceptors. Ann NY Acad Sci 635:475-476.

Lemos JR, Nowycky MC (1989) Two types of calcium channels coexist in peptide-releasing vertebrate nerve terminals. Neuron 2:1419-1426.

Llinás R, Steinberg IZ, Walton K (1981) Relationship between presynaptic calcium current and postsynaptic potential in squid giant synapse. Biophys J 33:323-352.

Loudes C, Faivre-Bauman A, Patte C, Tixier-Vidal A (1988) Involvement of DHP voltage-sensitive calcium channels and protein kinase $\mathrm{C}$ in thyroliberin (TRH) release by developing hypothalamic neurons in culture. Brain Res 456:324-332.

Lukasiewicz PD, McReynolds JS (1985) Synaptic transmission at $N$-mcthyl-D-aspartate receptors in the proximal retina of the mudpuppy. J Physiol (Lond) 367:99-115. 
Marc RE, Liu WS, Kalloniatis M, Raiguel SF, Van Haesendonck E (1990) Patterns of glutamate immunoreactivity in the goldfish retina. J Neurosci 10:4006-4034.

Maricq AV, Korenbrot JI (1988) Calcium and calcium-dependent chloride currents generate action potential in solitary cone photoreceptors. Neuron 1:503-515.

Miller RJ (1987) Multiple calcium channels and neuronal function. Science 235:46-52.

Neher E, Augustine GJ (1992) Calcium gradients and buffers in bovine chromattin cells. J Physiol (Lond) 450:273-301.

Nowycky MC, Fox AP, Tsien RW (1985) Three types of neuronal calcium channel with different calcium agonist sensitivity. Nature 316:440-443.

Perney TM, Hirning LD, Leeman SE, Miller RJ (1986) Multiple calcium channels mediate neurotransmitter release from peripheral neurons. Proc Natl Acad Sci USA 83:6656-6659.

Rane SG, Holz GG, Dunlap K (1987) Dihydropyridine inhibition of neuronal calcium current and substance $P$ release. Pfluegers Arch 409: 361-366.

Reynolds IJ, Wagner JA, Snyder SH, Thayer SA, Olivera BM, Miller RJ (1986) Brain voltage-sensitive calcium channel subtypes differentiated by $\omega$-conotoxin fraction GVIA. Proc Natl Acad Sci USA 83: 8804-8807.

Robitaille R, Adler EM, Charlton MP (1990) Strategic location of calcium channels at transmitter release sites of frog neuromuscular synapses. Neuron 5:773-779.

Saito T, Kujiraoka T (1982) Physiological and morphological identification of two types of on-center bipolar cells in the carp retina. $J$ Comp Neurol 205:161-170.

Sanguinetti MC, Kass RS (1984) Voltage-dependent block of calcium channel current in the calf cardiac Purkinje fiber by dihydropyridine calcium channel antagonists. Circ Res 55:336-348.

Slaughter MM, Miller RF (1983) Bipolar cells in the mudpuppy retina use an excitatory amino acid neurotransmitter. Nature 303:537-538.

Smith SJ, Augustine GJ, Charlton MP (1985) Transmission at voltageclamped giant synapse of the squid: evidence for cooperativity of presynaptic calcium action. Proc Natl Acad Sci USA 82:622-625.
Stanley EF, Atrakchi AH (1990) Calcium currents recorded from a vertebrate presynaptic nerve terminal are resistant to the dihydropyridine nifedipine. Proc Natl Acad Sci USA 87:9683-9687.

Suzuki S, Tachibana M, Kaneko A (1990) Effects of glycine and GABA on isolated bipolar cells of the mouse retina. J Physiol (Lond) 421: 645-662.

Tachibana M (1981) Membrane properties of solitary horizontal cells isolated from goldfish retina. J Physiol (Lond) 321:141-161.

Tachibana M (1985) Permeability changes induced by L-glutamate in solitary retinal horizontal cells isolated from Carassius auratus. $\mathrm{J}$ Physiol (Lond) 358:153-167.

Tachibana M, Okada T (1991) Release of endogenous excitatory amino acids from on-type bipolar cells isolated from the goldfish retina. J Neurosci 11:2199-2208.

Tachibana M, Okada T, Arimura T, Kobayashi K (1991) Properties, distribution and physiological meaning of calcium channels in ontype bipolar cells of the goldfish retina. Neurosci Res [Suppl] 16:S5.

Uto A, Arai H, Ogawa Y (1991) Reassessment of Fura-2 and the ratio method for determination of intracellular $\mathrm{Ca}^{2+}$ concentrations. Cell Calcium 12:29-37.

Wang X, Treistman SN, Lemos JR (1992) Two types of high-threshold calcium currents inhibited by $\omega$-conotoxin in nerve terminals of rat neurohypophysis. J Physiol (Lond) 445:181-199.

Williams DA, Fay FS (1990) Intracellular calibration of the fluorescent calcium indicator Fura-2. Cell Calcium 11:75-83.

Woodward JJ, Leslie SW (1986) Bay K 8644 stimulation of calcium entry and endogenous dopamine release in rat striatal synaptosomes antagonized by nimodipine. Brain Res 370:397-400.

Yawo H (1990) Voltage-activated calcium currents in presynaptic nerve terminals of the chicken ciliary ganglion. J Physiol (Lond) 428:199_ 213.

Yoshikami D, Bagabaldo Z, Olivera BM (1989) The inhibitory effects of omega-conotoxins on Ca channels and synapses. Ann NY Acad Sci $260: 230-248$. 